OPEN ACCESS

Edited by:

Anna Metaxas,

Dalhousie University, Canada

Reviewed by:

Pauline Chauvet,

Institut Français de Recherche pour l'Exploitation de la Mer (IFREMER),

France

Molly Timmers,

University of Hawai'i, at Mānoa,

United States

${ }^{*}$ Correspondence:

Aiswarya Gopal

gopalaiswarya@gmail.com

Specialty section: This article was submitted to Marine Ecosystem Ecology,

a section of the journal Frontiers in Marine Science

Received: 27 February 2020 Accepted: 04 August 2020

Published: 25 August 2020

Citation:

Gopal A, Abdul Jaleel KU, Parameswaran UV, Sanjeevan VN,

Saramma AV, Vijayan A,

Saravanane N, Gupta GVM and

Sudhakar M (2020) Distinctive

Community Patterns With Exceptional

Diversity of Polychaetes Around

a Tectonically Active Archipelago

in the Tropical Indian Ocean.

Front. Mar. Sci. 7:710.

doi: 10.3389/fmars.2020.00710

\section{Distinctive Community Patterns With Exceptional Diversity of Polychaetes Around a Tectonically Active Archipelago in the Tropical Indian Ocean}

\author{
Aiswarya Gopal'1*, K. U. Abdul Jaleel', Usha V. Parameswaran', V. N. Sanjeevan", \\ A. V. Saramma ${ }^{3}$, Anilkumar Vijayan ${ }^{1}$, N. Saravanane ${ }^{1}$, G. V. M. Gupta1 and M. Sudhakar ${ }^{1}$ \\ ${ }^{1}$ Centre for Marine Living Resources and Ecology, Ministry of Earth Sciences, Kochi, India, ${ }^{2}$ National Institute \\ of Oceanography Regional Centre, Kochi, India, ${ }^{3}$ Department of Marine Biology, Microbiology and Biochemistry, School \\ of Marine Sciences, Cochin University of Science and Technology, Kochi, India
}

Marine soft-sediments sustain functionally important benthic assemblages that are critical for remineralization of organic matter and supply of nutrients to the water column. While these assemblages are well studied along continental margins, investigations from insular margin that surround oceanic islands are very limited. This paper examines the distribution and standing stock of macrozoobenthos at 50, 100, and $200 \mathrm{~m}$ depth contours surrounding the Andaman and Nicobar archipelago in the tropical Indian Ocean. The standing stock of macrozoobenthos decreased from the mesophotic reef areas (50 $\mathrm{m}$ depth) to the deeper strata $(200 \mathrm{~m})$, particularly in the case of the dominant groups, the polychaetes and crustaceans. Smaller-sized, interstitial polychaetes and crustaceans were abundant in the coarser sandy sediments at the shallower sites. The polychaetes were represented by 606 species ( 279 genera) in the study, of which $>50 \%$ were rare species. Based on polychaete species composition, three regions were delineated in the study area - the Nicobar margin, the western margin of the Andaman (Bay of Bengal sector), and the eastern margin of the Andaman (Andaman Sea sector). The long, uninterrupted Andaman Island chain formed a geographic barrier separating the eastern and western margins, resulting in the regional distinctions in sediment nature and hydrographic characteristics, which in turn influenced species distribution. Corresponding differences were absent in the case of the Nicobar Islands, which are widely separated by transecting channels, permitting exchange of water between the Bay of Bengal and the Andaman Sea. Within the three regions, polychaete communities changed significantly in taxonomic and functional composition with increasing depth. The well oxygenated, coarse sandy sediments around mesophotic reefs $(50 \mathrm{~m})$ harbored predator-dominated assemblages. The $200 \mathrm{~m}$ sites, which were characterized by oxygen minimum conditions $\left(<0.5 \mathrm{ml} . \mathrm{I}^{-1}\right)$, particularly around the Andaman Island mass, were dominated by deposit feeders. This study provides the first 
comprehensive dataset on distribution and standing stock of macrozoobenthos, and community structure of polychaetes along the Andaman and Nicobar insular margin. It also revealed the highest number of polychaete species ever recorded in the northern Indian Ocean, indicating that the Andaman and Nicobar margin is a significant marine biodiversity hotspot.

Keywords: benthos, polychaetes, Andaman and Nicobar, mesophotic reefs, biodiversity, islands, benthic ecology

\section{INTRODUCTION}

Insular margins surrounding tropical oceanic islands are pristine, species-rich environments, with high rates of endemism (Allen, 2008; Anderson et al., 2013). Located beyond the nearshore coral reef framework, they consist of extensive softsediments, which can sustain functionally important and diverse benthic assemblages. Soft sediments around reefs comprise of skeletal fragments of reef-forming and reef-associated calcifying organisms, which undergo changes in grain size and morphology as a result of hydrodynamic activity and bioerosion (Janßen et al., 2017). Coral reefs, thus, exert strong influence on the sediment dynamics in surrounding shallow-water, mesophotic and deepsea areas (Sherman et al., 2016). The nature of sediments in turn influence the structure of benthic communities, even at substantial distances from the reefs (Riddle, 1988; Demopoulos et al., 2014; Sibaja-Cordero et al., 2016).

In oligotrophic systems, such as around oceanic islands associated with coral reefs, the bioturbation and remineralization of sedimentary organic matter by benthic fauna is of critical importance to supply nutrients back to the water column, thereby sustaining biological production (Snelgrove, 1998; Griffiths et al., 2017). Macrozoobenthos (benthic fauna $>300 \mu \mathrm{m}$ ), are of particular importance in this regard and account for the bulk of the benthic standing stock (Rex et al., 2006), with polychaetes as a dominant group (Hutchings, 1998; Levin et al., 2000). The ubiquity of polychaetes in soft sediments is due to their functional diversity (Snelgrove, 1999), as they can utilize organic matter as food either directly (i.e., deposit feeders and suspension feeders) or indirectly (e.g., predation and scavenging) (Fauchald and Jumars, 1979; Jumars et al., 2015). They also exhibit a wide range of reproductive strategies from brooding to broadcast spawning, enabling species dispersal to suitable habitats even at great distances (Carson and Hentschel, 2006). While polychaetes as a group are ubiquitous in soft-sediments, the $\sim 12,000$ species show significant spatial patterns in distribution, under the influence of the environmental gradients existing in the marine realm. These include direct physical and chemical gradients (e.g., sediment grain size, temperature, salinity, oxygen, pressure), and resource gradients (e.g., food availability), as well as indirect gradients (depth, latitude etc.) (McArthur et al., 2010). The sessile or sedentary life mode of polychaetes, and their communitylevel responses to changes in environmental conditions, make them good indicators of ecosystem health (Giangrande et al., 2005). They are thus used as surrogates for estimation of diversity, dynamics and functioning of benthic communities (Olsgard et al., 2003).
While the responses of macrozoobenthic communities to environmental settings along continental margins have been well studied, investigations around island ecosystems have been limited, especially in the tropical Indian Ocean (Ingole et al., 1992; Mackie et al., 2005; Bigot et al., 2006; Ibrahim et al., 2006; Dahanayaka et al., 2007; Nassaj et al., 2010), with little attention on benthic biodiversity and ecology of soft sediments beyond the shallow-water reefs (Parulekar and Ansari, 1981; Ansari et al., 1990, 1991; Rivonker and Sangodkar, 1997; Susan et al., 2014). The Andaman and Nicobar Island (ANI) arc complex located between the Bay of Bengal and the Andaman Sea in the tropical Indian Ocean, is composed of 572 islands and is surrounded by fringing reefs (Brown, 2005). The Andaman and Nicobar Islands (terrestrial) are one of the 35 biodiversity hotspots of the world (Myers et al., 2000; Williams et al., 2011; Marchese, 2015), of which the Andaman Islands are included in the Indo-Burmese hotspot and Nicobar Islands in the Sundaland hotspot. The archipelago is situated close to the Coral Triangle, an epicenter of marine biodiversity, and has a geographic continuity with the Malay Archipelago. The Andaman Sea has continuous water exchange with the Indian Ocean, Bay of Bengal, and the South China Sea, which plays a significant role in species dispersal.

Being entirely landlocked to the north, the northern Indian Ocean is characterized by latitudinal trends in productivity, as a result of complex, seasonal physical oceanographic processes (e.g., coastal upwelling, convective mixing, eddies). The benthic fauna of the northern Indian Ocean (continental) margins, thus exhibit latitudinal, bathymetric as well as seasonal variations in standing stock and community structure. However, nothing is known regarding spatial trends in composition of soft-sediment macrozoobenthos in the Andaman and Nicobar archipelago. The continental margins of the northern Indian Ocean (e.g., east and west coast of Indian peninsula) are subjected to intense anthropogenic stressors like pollution and trawling disturbances. While such stressors are less intense around the ANI, the region is more vulnerable to climate-change related ocean warming and acidification. These have severe impacts on the coral reefs (e.g., coral reef bleaching), as well as surrounding benthic communities (Glynn, 1993; Hoegh-Guldberg, 1999). Extensive bleaching events are being reported in the reefs of the Andaman and Nicobar archipelago (Mondal et al., 2014; Mohanty et al., 2017). Apart from this, the Andaman Nicobar Islands, which are situated on a tectonically active margin (Curray, 2005), are vulnerable to earthquakes and tsunamis. The devastating Boxing Day Tsunami in 2004 caused widespread destruction along coastlines and reefs of the archipelago (Brown, 2005). 
The impacts of the tsunami on the benthic communities around the islands could not be assessed owing to the lack of data prior to this event.

The present study is a pioneer attempt to describe the macrozoobenthic standing stock and community structure of polychaetes in the insular margin that surround the Andaman and Nicobar Islands (ANI). We hypothesize that (a) the soft sediments in mesophotic reef areas harbor high diversity of polychaetes, and (b) macrozoobenthic standing stock and polychaete species composition in the insular margin exhibit bathymetric and latitudinal distribution patterns, under the influence of environmental settings, as observed in tropical continental margins. We test these hypotheses by characterizing (1) macrozoobenthic abundance and diversity metrics of soft sediment polychaetes across depth and latitude, (2) polychaete species composition and feeding guilds across depth and latitude, and (3) how these relate to environmental factors. This is the first systematic study to examine, both quantitatively and qualitatively, the traits of macrozoobenthos in the insular margin of the Andaman and Nicobar archipelago.

\section{MATERIALS AND METHODS}

\section{Study Area}

The Andaman and Nicobar Islands (ANI) are oriented in a northsouth arc, between $6^{\circ}$ and $14^{\circ} \mathrm{N}$ and $92^{\circ}$ to $94^{\circ} \mathrm{E}$, in the eastern Bay of Bengal. The islands are volcanic in origin, located on the Andaman Nicobar Ridge system, at the western edge of the Burma microplate. The boundary between the Burma and Sunda plate, which lies to the east of the ridge, is a marginal seafloor spreading center. To the west, the boundary with the Indian plate is an area of extensive ongoing subduction (Curray, 2005). The island arc is divided into groups by transecting channels, and the southern part of the Andaman Sea is connected to the South China Sea through the Malacca Strait (Figure 1). The islands are surrounded by fringing coral reefs (Brown, 2005). Beyond these reefs, the deeper areas of the Bay of Bengal and Andaman basins receive substantial sediment inflow from the GangaBrahmaputra and the Ayeyarwady river systems, respectively (Rodolfo, 1969). The eastern slopes of the Andaman and Nicobar ridge system is characterized by underwater structures like the Sewell Seamount, Alcock Rise, Invisible Bank, Central Andaman and Nicobar rift valleys, as well as other sea highs and canyons (Rao and Kessarkar, 2001). The Andaman and Nicobar Islands are drained by numerous small streams, and 5 rivers - the Kalpong River (draining into the eastern side of the North Andaman Island at $13^{\circ} 09^{\prime} 16^{\prime \prime} \mathrm{N}, 92^{\circ} 58^{\prime} 02^{\prime \prime} \mathrm{E}$ ) and the Galathea River (draining into the southern tip of the Great Nicobar Island at $6^{\circ} 48^{\prime} 57^{\prime \prime} \mathrm{N}, 93^{\circ} 51^{\prime} 05^{\prime \prime} \mathrm{E}$ ), along with the Alexandria, Dogmar and Amrit Kaur Rivers (draining into the western side of the Great Nicobar Island between $7^{\circ} \mathrm{N}$ and $\left.7^{\circ} 9^{\prime} 40^{\prime} \mathrm{N}\right)$. The only quantitative investigation on the benthic fauna (11$2150 \mathrm{~m}$ ) around the Andaman Nicobar Islands was carried out by Parulekar and Ansari (1981), and till date a systematic study on the quantitative and qualitative traits of macrozoobenthos has not been attempted.

\section{Sample Collection and Analysis}

Systematic sampling was carried out onboard Fishery and Oceanographic Research Vessel (FORV) Sagar Sampada along the insular margin of the Andaman and Nicobar archipelago $\left(6^{\circ} 26^{\prime} \mathrm{N}\right.$ to $13^{\circ} 32^{\prime} \mathrm{N}$ and $92^{\circ} 11^{\prime} \mathrm{E}$ to $93^{\circ} 59^{\prime} \mathrm{E}$, Figure 1 and Supplementary Table S1), in three depth strata (50, 100, and $200 \mathrm{~m}$ ), covering the Bay of Bengal (western margin of the islands) and Andaman Sea (eastern margin of the islands) sectors. Two surveys FORVSS 261 (S1, January 2009) and FORVSS 292 (S2, November-December 2011) were conducted during northeast monsoon season (NEM), covering a total of 111 sites along 23 bathymetric transects. Hydrographic parameters (near bottom temperature, salinity and dissolved oxygen) of bottom seawater were recorded from 96 sites (37 sites in S1 and 59 sites in S2) using a Conductivity Temperature Depth (CTD) profiler (Model SBE 911). Although grab sampling was attempted in 111 sites, sampling was successful only in 89 sites while the bottom was hard in the remaining sites. Samples from all 89 sites were used for texture and organic matter analysis, while samples from 80 sites (i.e., grab samples having $>80 \%$ sediments) were included in biological data analysis (30 sites, 17 transects in S1; 50 sites, 20 transects in S2). The map of the study area was plotted using ArcGIS 10.7.1 (Data used for plotting: GEBCO for bathymetry and USGS for plate boundaries).

A modified Smith-McIntyre grab having a bite area of $0.2 \mathrm{~m}^{2}$ was operated for collecting sediments during S1, while in S2, a grab with a $0.1 \mathrm{~m}^{2}$ bite area was used. Approximately $100 \mathrm{~g}$ of sediment sample from each grab was first collected using a scoop, sealed and refrigerated at $-20^{\circ} \mathrm{C}$ for estimation of organic matter and sediment texture analysis. Test sieves of 500 and $300 \mu \mathrm{m}$ mesh sizes were used for separating macrozoobenthos in S1 and S2, respectively. After sieving, the residual sediments with organisms were narcotized using magnesium chloride solution, preserved in 5\% buffered Formalin-Rose Bengal solution and labeled. Organic carbon content of the sediment was determined by the wet oxidation method (El-Wakeel and Riley, 1957) in the shore lab and then converted into organic matter content (Trask, 1939). Sediment texture analysis was done using a CILAS 1180 particle size analyzer and data on percentage composition of sand (63-2000 $\mu \mathrm{m})$, silt $(4-63 \mu \mathrm{m})$ and clay $(<4 \mu \mathrm{m})$ were obtained following the classification of Shepard (1954), along with median grain size (MGZ) of sediments. Sediments that were coarser, and therefore not suitable for analysis through the particle size analyzer, were subjected to serial sieving (at half $\Phi$ intervals), and data on sediment texture was extracted using GRADISTAT v8.

The sediment samples with organisms were sieved again in the shore lab and sorted to group level (polychaetes, crustaceans, molluscs, echinoderms and 'other faunal groups') and were enumerated to generate group abundance data, which was expressed as individuals per square meter (ind. $\mathrm{m}^{-2}$ ). Wet weight biomass of each group was determined using a high precision electronic balance of $\pm 0.1 \mathrm{mg}$ accuracy (Metler Toledo ML204) and expressed in grams per square meter $\left(\mathrm{g} \cdot \mathrm{m}^{-2}\right)$. Polychaetes were identified to family and genus level using Fauchald (1977) and Rouse and Pleijel (2001) and species identification was done using standard keys, taxonomic revisions and taxonomic publications from the northern Indian Ocean 

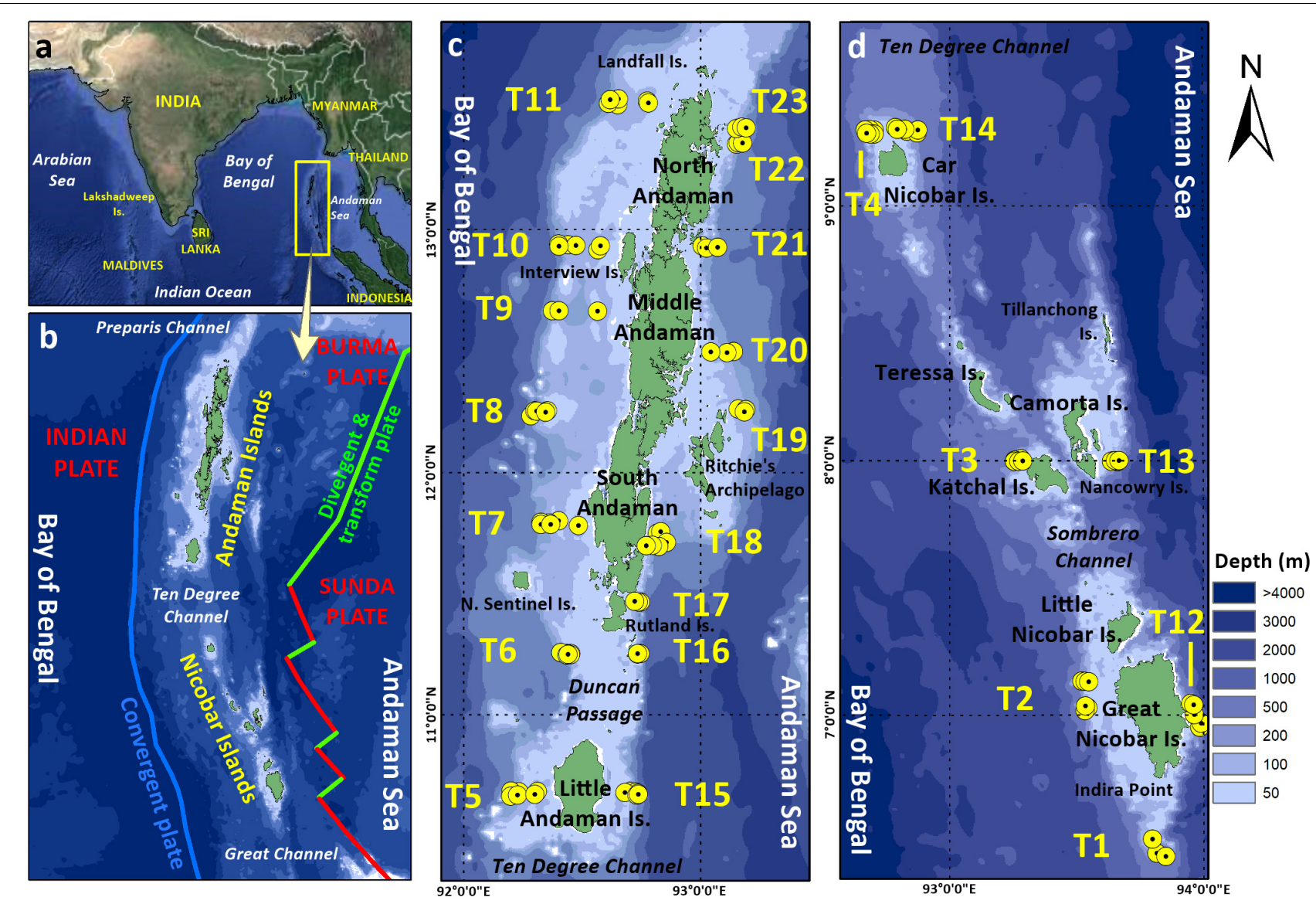

FIGURE 1 | Map showing (a) location of the Andaman and Nicobar Islands in the northern Indian Ocean, (b) entire Andaman and Nicobar Archipelago with limits of tectonic plates, (c) Andaman Islands, and (d) Nicobar Islands. Yellow (•) represents sampling sites.

(e.g., Fauvel, 1953) and the Andaman Sea (e.g., Böggemann and Eibye-Jacobsen, 2002; Eibye-Jacobsen, 2002). Photographs of polychaetes were taken using the compound microscope (Leica DM1000) with image analyzer. In order to understand the functional composition of their communities, polychaete species were assigned to feeding guilds like predators (PR), surface deposit feeders (SDF), sub-surface deposit feeders (SSDF) and suspension feeders (SF), based on the classification of Fauchald and Jumars (1979) and Jumars et al. (2015). Latitudinal variations in the macrozoobenthic standing stock, polychaete species composition and feeding guild composition of polychaetes were analyzed only in S2 as fewer transects were covered successfully along the eastern margin of the Andaman and Nicobar Islands in S1.

\section{Statistical Analysis}

Spatial variations in environmental parameters (log transformed and normalized) were tested using one-way ANOVA in IBM SPSS 20 and through a Principal Component Analysis (PCA) using Plymouth Routines in Multivariate Ecological Research (PRIMER-6). PCA was done on 89 sites samples where both hydrographic and sediment parameters were present. For depicting the range of faunal abundance, biomass and diversity indices at each depth stratum, box-and-whisker plots were used. Univariate measures of polychaete species diversity (Hill Numbers) at each site, namely, species number (N0), Shannon's exponential index (N1) and Simpson's reciprocal index (N2), were measured using PRIMER-6. Higher taxonomy of the polychaete species was obtained from the World Register of Marine Species (World Register of Marine Species [WoRMS], $2020)^{1}$ and this was used to generate a taxonomic funnel plot, which depicts the number of species against the taxonomic distinctness $(\Delta+)$, and also gives a probability funnel (95\%) based on the master taxonomic tree (Clarke and Warwick, 2001). Bathymetric and latitudinal variations in macrozoobenthos abundance, biomass, diversity indices and polychaete species composition (using square-root transformation and Bray-Curtis similarity) and environmental parameters (log-transformation, normalization, and Euclidean distance) were tested using the PERMANOVA add-on in PRIMER-6 (Anderson et al., 2008). The ordination of sites according to the similarity matrix of polychaete species (square-root transformed species abundance data and Bray-Curtis similarity) was visualized by non-metric multidimensional scaling (nMDS) using vegan

${ }^{1}$ http://www.marinespecies.org/aphia.php?p=taxdetails\&id=883 
A

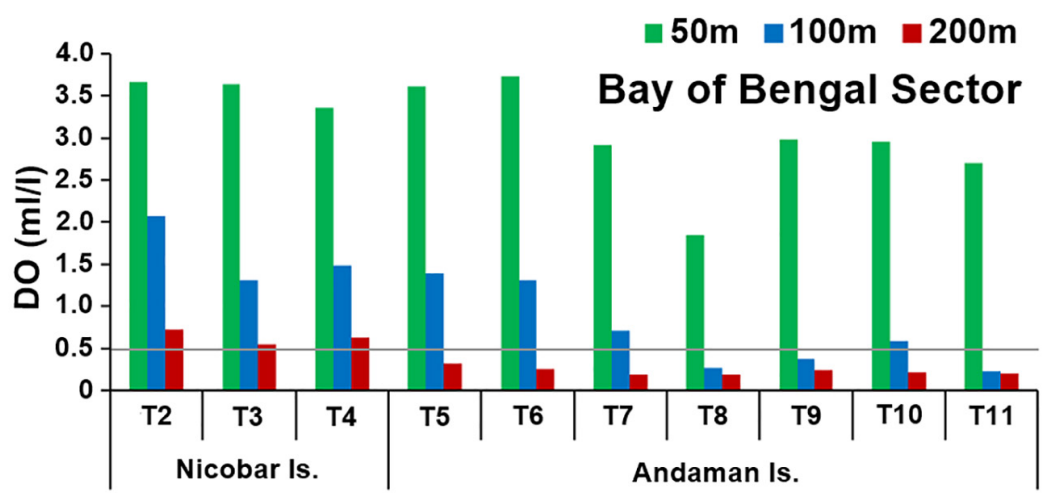

B

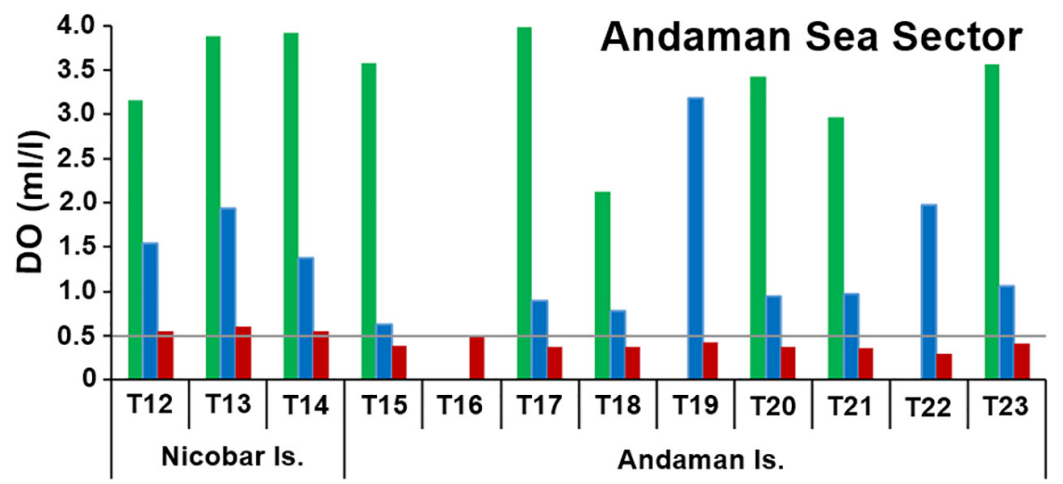

FIGURE 2 | Bottom water dissolved oxygen $\left(\mathrm{ml.}^{-\mathrm{I}^{-1}}\right.$ ) at $50 \mathrm{~m}$ (green bars), $100 \mathrm{~m}$ (blue bars) and $200 \mathrm{~m}$ (red bars) depth strata in the (A) Bay of Bengal Sector (BoB) (B) Andaman Sea sector (AS).

package in $\mathrm{R}$, with a contour at 95\% confidence level. A Similarity Percentage (SIMPER) analysis (PRIMER-6) was used to identify the polychaete species causing the observed similarity or dissimilarity among the clusters obtained in the nMDS. Canonical Correspondence analysis (CCA) was carried out using CANOCO 4.5, to elucidate the preferences of these species to specific sets of environmental conditions (ter Braak and Smilauer, 2002). For this analysis a subset of 50 species was used, including dominant species in the area (contributing $>1 \%$ of total abundance in the study) as well as those responsible for the regional and bathymetric distinctions (contributing $>1 \%$ to dissimilarity in SIMPER analysis). The abundance of feeding guilds of polychaetes in each site were superimposed as bubbles on the PCA plot to depict the environmental preferences of each guild.

\section{RESULTS}

\section{Environmental Parameters}

In the Andaman and Nicobar Island (ANI) margin, bottom water temperature $\left(F_{2,93}=564.090, p<0.01\right)$, salinity $\left(F_{2,93}=158.288, p<0.01\right)$ and dissolved oxygen $\left(F_{2,93}=79.594\right.$, $p<0.01)$ exhibited significant variations with depth. In general, temperature and dissolved oxygen (DO) decreased with increasing depth, while salinity increased with depth. Latitudinal variation in temperature and salinity were not significant $(p>0.01)$ in any of the depth strata $(50,100,200 \mathrm{~m})$. Oxygen minimum conditions $\left(<0.5 \mathrm{ml} . \mathrm{l}^{-1}\right)$ were recorded in the $200 \mathrm{~m}$ contour of Bay of Bengal (BoB) and Andaman Sea (AS) sectors, and even at $100 \mathrm{~m}$ depth (north of $12^{\circ} \mathrm{N}$ ) in the BoB sector (Figures 2A,B). As a result, significant latitudinal variations were only observed in DO at the $200 \mathrm{~m}$ depth stratum in the BoB sector $\left(F_{9,9}=29.968, p<0.01\right)$. Significant differences between surveys were not observed in near-bottom hydrographic parameters $(p>0.05)$. The southernmost transect (T1) which is north-south oriented exhibited DO values similar to the Bay of Bengal Sector at the $50 \mathrm{~m}\left(3.96 \mathrm{ml} . \mathrm{l}^{-1}\right)$ and $100 \mathrm{~m}$ depths $\left(1.28 \mathrm{ml} . \mathrm{l}^{-1}\right)$. Mean values of hydrographic and sediment parameters in the study area are presented in Table $\mathbf{1 .}$

In the ANI margin, sand was the major fraction in all three depth strata. The surface sediments were predominantly coarse coralline sand in the shallow depths $(50 \mathrm{~m})$, silty sand in intermediate depths $(100 \mathrm{~m})$ and sandy silt in the higher depths $(200 \mathrm{~m})$. Significant variations in relative proportion of sand $\left(F_{2,86}=6.389, p=0.003\right)$, silt $\left(F_{2,86}=7.597, p=0.001\right)$ and clay $\left(F_{2,86}=11.880, p=0.001\right)$ as well as median grain size $\left(\mathrm{MGZ}, F_{2,86}=8.725, p<0.001\right)$ were prominent among the depth strata. Latitudinal variations in sand $\left(F_{9,8}=33.266\right.$, $p<0.001)$, silt $\left(F_{9,8}=34.941, p<0.001\right)$ and clay $\left(F_{9,8}=10.405\right.$, $p<0.002)$ content as well as MGZ $\left(F_{9,8}=6.215, p=0.009\right)$ were significant in the $50 \mathrm{~m}$ depth stratum in the BoB sector (Figure 3A). In this sector, significant variations were noted only in sand $\left(F_{9,6}=4.729, p=0.036\right)$ and $\operatorname{MGZ}\left(F_{9,6}=6.217\right.$, 
TABLE 1 | Hydrographic and sediment characteristics at each depth stratum [mean $\pm \mathrm{SD}, n=$ No. of samples].

\begin{tabular}{|c|c|c|c|c|c|c|}
\hline \multirow[t]{3}{*}{ Response } & \multicolumn{3}{|c|}{ Survey 1} & \multicolumn{3}{|c|}{ Survey 2} \\
\hline & $50 \mathrm{~m}$ & $100 \mathrm{~m}$ & $200 \mathrm{~m}$ & $50 \mathrm{~m}$ & $100 \mathrm{~m}$ & $200 \mathrm{~m}$ \\
\hline & $n=10$ & $n=11$ & $n=16$ & $n=20$ & $n=20$ & $n=19$ \\
\hline \multicolumn{7}{|l|}{ No. of water samples } \\
\hline Temperature $\left({ }^{\circ} \mathrm{C}\right)$ & $27.65 \pm 0.31$ & $25.35 \pm 1.97$ & $14.22 \pm 0.88$ & $27.23 \pm 0.76$ & $21.22 \pm 1.63$ & $13.89 \pm 0.79$ \\
\hline Salinity & $32.82 \pm 0.41$ & $33.82 \pm 0.43$ & $34.93 \pm 0.05$ & $33.49 \pm 0.39$ & $34.51 \pm 0.15$ & $34.93 \pm 0.04$ \\
\hline Dissolved oxygen $\left(\mathrm{ml} . \mathrm{I}^{-1}\right)$ & $4.03 \pm 0.17$ & $2.61 \pm 0.68$ & $0.45 \pm 0.19$ & $3.29 \pm 0.59$ & $1.06 \pm 0.51$ & $0.39 \pm 0.17$ \\
\hline No. of sediment samples & $n=10$ & $n=10$ & $n=15$ & $n=19$ & $n=18$ & $n=17$ \\
\hline Sand (\%) & $87.66 \pm 25.57$ & $79.71 \pm 23.23$ & $51.94 \pm 25.96$ & $74.16 \pm 31.88$ & $77.00 \pm 28.48$ & $61.13 \pm 26.57$ \\
\hline Silt (\%) & $10.28 \pm 23.95$ & $13.51 \pm 15.85$ & $32.17 \pm 21.80$ & $17.30 \pm 23.76$ & $13.46 \pm 15.64$ & $31.22 \pm 20.70$ \\
\hline Clay (\%) & $2.07 \pm 1.88$ & $6.79 \pm 6.17$ & $15.88 \pm 11.36$ & $3.27 \pm 3.81$ & $4.01 \pm 6.46$ & $7.71 \pm 7.14$ \\
\hline Median grain size $(\mu \mathrm{m})$ & $371.24 \pm 153.74$ & $231.03 \pm 161.83$ & $90.93 \pm 96.93$ & $253.20 \pm 205.61$ & $234.72 \pm 181.27$ & $144.28 \pm 150.89$ \\
\hline Organic matter (\%) & $0.69 \pm 0.58$ & $0.64 \pm 0.37$ & $0.97 \pm 0.92$ & $0.60 \pm 0.40$ & $0.55 \pm 0.33$ & $1.46 \pm 1.16$ \\
\hline
\end{tabular}

$p=0.019)$ at $100 \mathrm{~m}$ depth, and silt $\left(F_{9,9}=29.968, p<0.001\right)$ and $\operatorname{MGZ}\left(F_{9,9}=8.564, p=0.002\right)$ at $200 \mathrm{~m}$ depth. In the AS sector (Figure 3B), significant latitudinal variations were noted in clay content $\left(F_{7,3}=9.006, p=0.049\right)$ and MGZ $\left(F_{7,3}=13.215, p=0.029\right)$ at $100 \mathrm{~m}$ depth and in clay content $\left(F_{7,3}=9.006, p=0.049\right)$ at $200 \mathrm{~m}$ depth. Organic matter $(\mathrm{OM})$ content was relatively higher in sandy silt sediments compared to coralline sands, and showed significant bathymetric variations $\left(F_{2,86}=7.883, p=0.001\right)$. Latitudinal variations in $\mathrm{OM}$ were significant only in the $100 \mathrm{~m}\left(F_{9,6}=6.217, p=0.019\right)$ and $200 \mathrm{~m}\left(F_{9,9}=8.564, p=0.002\right)$ depth strata of BoB sector (Figures 3A,B). The sediment texture in southern tip transect (T1) was coralline sand with pebbles at both 50 and $100 \mathrm{~m}$ depths.

The variations in environmental parameters with respect to depth are depicted in the PCA plot (Figure 4). In this analysis 5 principal components explained $97.2 \%$ of variance between sites, with 2 significant axes (PC1 and PC2) explaining 83\% of the total variance (Supplementary Table S2). PC1 axis (eigenvalue 4.83), clearly explains the variations in sediment characteristics (sand, silt, clay, OM, MGZ) while PC2 axis (eigenvalue 1.81) explained variations in the hydrographic parameters (temperature, salinity, DO). The shallow sites $(50 \mathrm{~m})$ of Andaman and Nicobar Islands were characterized by well oxygenated coralline sandy sediments with low OM content. The intermediate depth stratum $(100 \mathrm{~m})$ was characterized by silty sand off Andaman Islands and sand around the Nicobar Islands, except for T11 and T18, where sediments were a proportionate mixture of sand, silt and clay, with high OM content. The deeper sites $(200 \mathrm{~m})$ had poorly oxygenated sandy silt sediments and high OM content. Some sites (T19 and T21) harbored clayey silt sediments at this depth, with relatively higher OM content. The higher depths (200 m sites) around Nicobar Islands were characterized by relatively higher sand content than the Andaman Islands.

\section{Standing Stock of Macrozoobenthos}

Mean density of macrozoobenthos in the second survey $\left(1834 \pm 890\right.$ ind. $\left.\mathrm{m}^{-2}, 300 \mu \mathrm{m}\right)$ was higher than in the first survey $\left(1131 \pm 586\right.$ ind. $\left.\mathrm{m}^{-2}, 500 \mu \mathrm{m}\right)$, but mean biomass was comparable in both $\left(4.99 \pm 2.58\right.$ g.m ${ }^{-2}, 500 \mu \mathrm{m}, \mathrm{S} 1$ and $4.73 \pm 2.23$ g.m $\left.{ }^{-2}, 300 \mu \mathrm{m}, \mathrm{S} 2\right)$. Significant bathymetric variations were observed in density and biomass only in the second survey $(300 \mu \mathrm{m})$ (Table 3$)$. The shallow depth stratum $(50 \mathrm{~m})$ harbored maximum density and biomass, with a gradual decrease toward higher depths (200 m) (Table 2), which was more prominent in S2. Latitudinal variations in density and biomass of macrozoobenthos were not found to be significant $(p>0.05)$.

Among the 33 higher level taxa identified in the study, polychaetes and crustaceans were the most abundant groups. Polychaetes contributed 65\% (500 $\mu \mathrm{m}, \mathrm{S} 1)$ and 61\% (300 $\mu \mathrm{m}$, S2) to macrozoobenthic density; and 57\% (500 $\mu \mathrm{m}, \mathrm{S} 1)$ and 53\% (300 $\mu \mathrm{m}, \mathrm{S} 2$ ) to macrozoobenthic biomass (Table 2). Polychaete density (Figure 5A) decreased significantly with increasing depth in the finer mesh $(300 \mu \mathrm{m}$, S2) but not in the coarser mesh $(500 \mu \mathrm{m}, \mathrm{S} 1)$, whereas significant variations were not observed in polychaete biomass in either survey (Table 3). Crustaceans were the second dominant group among macrozoobenthos, contributing 37\% (500 $\mu \mathrm{m}, \mathrm{S} 1)$ and $33 \%$ (300 $\mu \mathrm{m}, \mathrm{S} 2)$ to macrozoobenthic density; and 19\% (500 $\mu \mathrm{m}, \mathrm{S} 1$ ) and 25\% (300 $\mu \mathrm{m}, \mathrm{S} 2)$ to macrozoobenthic biomass (Table 2). Amphipods were the dominant group among crustaceans (72\% $500 \mu \mathrm{m}, \mathrm{S} 1 ; 83 \% 300 \mu \mathrm{m}, \mathrm{S} 2)$, while other crustacean taxa such as caprellids, isopods, tanaids, cumaceans, mysids and small crabs each contributed less than 1\% (Supplementary Table S3). Crustacean density and biomass decreased significantly with increasing depth in both surveys (Table 3). Density of crustaceans decreased from south to north at the $200 \mathrm{~m}$ depth stratum in both BoB and AS sectors. Molluscs, echinoderms and other groups contributed $\leq 1 \%$ of the macrozoobenthic density in the study area. However, owing to their larger size, molluscs and echinoderms contributed up to $12 \%$ to macrozoobenthic biomass.

\section{Species Diversity of Polychaetes}

A total of 606 species of polychaete belonging to 279 genera and 52 families were recorded from the insular margin of Andaman and Nicobar Islands (ANI) during the present study. In the first survey $(\mathrm{S} 1,500 \mu \mathrm{m}), 338$ species of polychaetes were recorded, belonging to 179 genera and 43 families. In the second survey (S2, $300 \mu \mathrm{m}), 480$ species belonging to 250 genera and 52 families were observed (Figures 6A,B). The numerically 


\section{A Bay of Bengal sector}

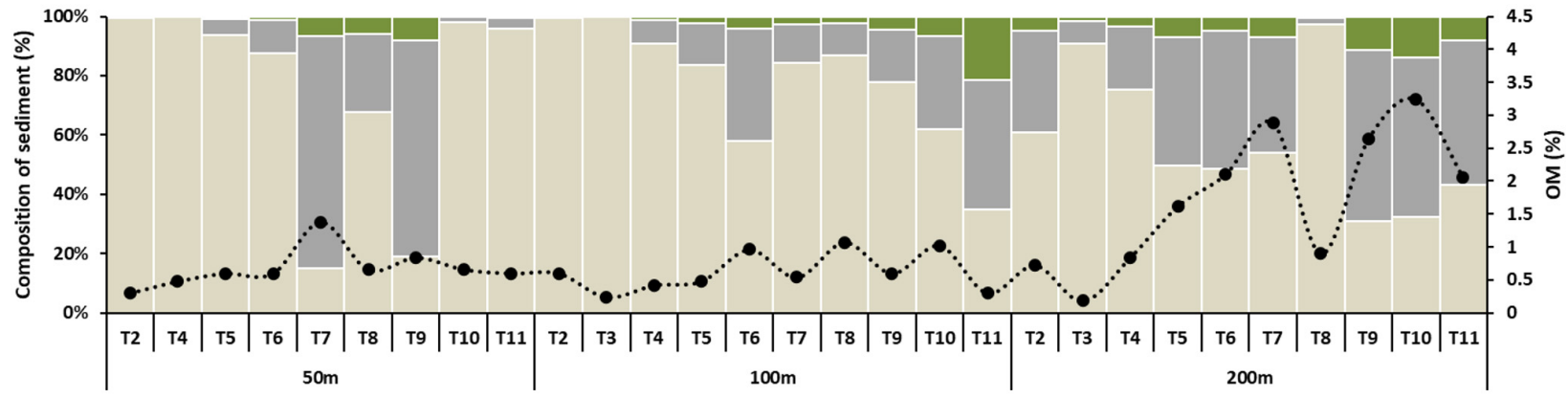

\section{B Andaman Sea sector}

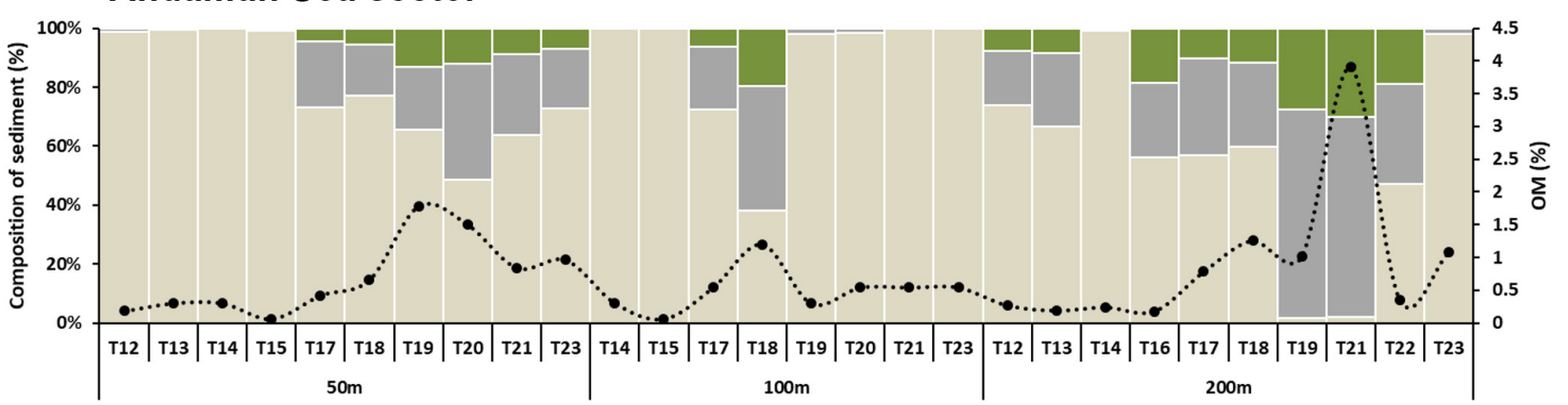

FIGURE 3 | Percentage composition of sand, silt, clay at 50, 100, and $200 \mathrm{~m}$ depth strata along (A) Bay of Bengal sector (BoB), and (B) Andaman Sea sector (AS). Black (•) represents the organic matter content (OM\%) at each site.

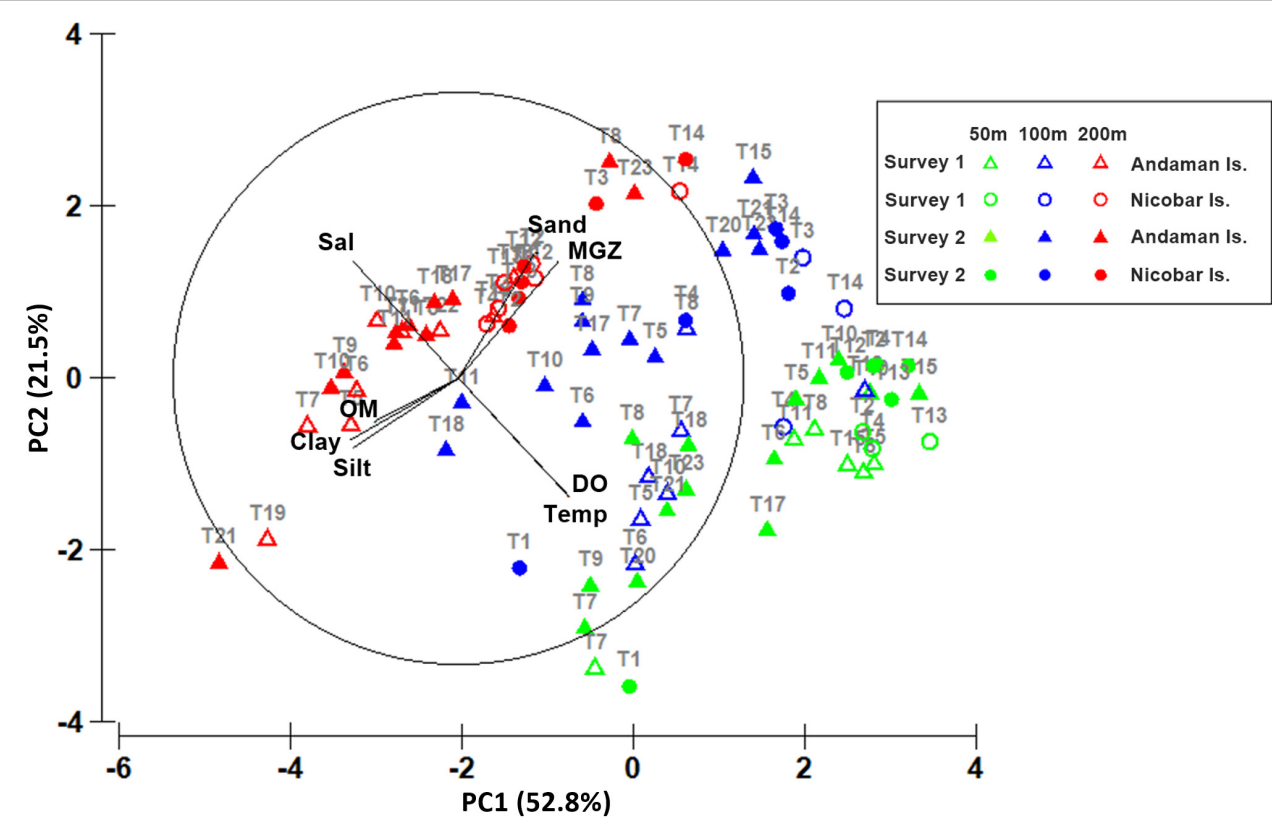

FIGURE 4 | Principal Component Analysis (PCA) showing ordination of sites with respect to spatial variations in environmental factors (arrows: Temp-Temperature, Sal-Salinity, DO-Dissolved oxygen, Sand, Silt, Clay, MGZ-Median grain size, OM-Organic matter) at $50 \mathrm{~m}$ (green), $100 \mathrm{~m}$ (blue) and $200 \mathrm{~m}$ (red) depth strata around Andaman Islands $(\boldsymbol{\Lambda})$ and Nicobar Islands (•) in survey 1 (hollow symbols) and survey 2 (filled symbols). 
TABLE 2 | Density (ind. $\mathrm{m}^{-2}$ ) and wet weight biomass $\left(\mathrm{g} \cdot \mathrm{m}^{-2}\right.$ ) of macrozoobenthic groups at each depth strata [mean $\pm \mathrm{SD}, n=$ No. of samples].

\begin{tabular}{|c|c|c|c|c|c|c|c|}
\hline \multirow[t]{2}{*}{ Standing stock } & \multirow{2}{*}{$\frac{\text { Surveys (mesh size) }}{\text { Depths }}$} & \multicolumn{3}{|c|}{ Survey $1(500 \mu \mathrm{m})$} & \multicolumn{3}{|c|}{ Survey $2(300 \mu \mathrm{m})$} \\
\hline & & $50 \mathrm{~m}(n=10)$ & $100 \mathrm{~m}(n=7)$ & $200 \mathrm{~m}(n=13)$ & $50 \mathrm{~m}(n=19)$ & $100 \mathrm{~m}(n=16)$ & $200 \mathrm{~m}(n=15)$ \\
\hline & Polychaetes & $579 \pm 218$ & $622 \pm 423$ & $800 \pm 578$ & $1482 \pm 472$ & $1095 \pm 440$ & $927 \pm 544$ \\
\hline & Crustaceans & $816 \pm 440$ & $306 \pm 301$ & $170 \pm 120$ & $1099 \pm 416$ & $446 \pm 366$ & $154 \pm 120$ \\
\hline Wet weight biomass $\left(\mathrm{g} \cdot \mathrm{m}^{-2}\right)$ & Macrozoobenthos & $5.75 \pm 2.60$ & $4.70 \pm 2.7$ & $4.61 \pm 2.57$ & $5.42 \pm 1.47$ & $5.04 \pm 2.56$ & $3.52 \pm 2.27$ \\
\hline
\end{tabular}

dominant polychaetes in the S1 $(500 \mu \mathrm{m})$ were Aphelochaeta filibranchia (4.54\%), Levinsenia oculata (4.43\%), Kirkegaardia dorsobranchialis (4.28\%) while in the S2 (300 $\mu \mathrm{m})$ Ampharete agulhasensis (2.91\%), Prionospio (Minuspio) spp. (2.86\%) and Spiophanes spp. (2.72\%) were abundant.

Out of 606 species of polychaetes, 306 species had limited occurrence (212 singletons and 94 doubletons) in the study area (Figure 7A). The degree of rarity (Figure 7B) was higher in the mesophotic reef areas (207 singleton species at $50 \mathrm{~m}$ ) when compared to higher depths (155 and 137 singletons at 100 and $200 \mathrm{~m}$, respectively). The singleton and doubleton species (Supplementary Table S4) were relatively higher in S2 $(300 \mu \mathrm{m})$ compared to S1 $(500 \mu \mathrm{m})$. The study area was characterized by high species number [N0 (S): $46 \pm 14(500 \mu \mathrm{m}$, S1); $49 \pm 17$ (300 $\mu \mathrm{m}, \mathrm{S} 2)]$, Shannon's exponential index [N1: $25.22 \pm 8.79(500 \mu \mathrm{m}, \mathrm{S} 1) ; 33.77 \pm 12.37(300 \mu \mathrm{m}, \mathrm{S} 2)]$ and Simpson's reciprocal index $[\mathrm{N} 2: 16.33 \pm 6.75(500 \mu \mathrm{m}, \mathrm{S} 1)$; $23.45 \pm 9.71(300 \mu \mathrm{m}, \mathrm{S} 2)]$. These indices decreased significantly with increasing depth, only in S2 $(300 \mu \mathrm{m})$ (Figures 5B-D; Table 3, and Supplementary Table S5). Latitudinal variations in diversity indices were significant only along the $200 \mathrm{~m}$ contour (N0: $p$ seudo- $F=5.906, p=0.024 ; \mathrm{N} 1:$ sseudo $-F=6.427, p=0.03$; $\mathrm{N} 2$ : pseudo- $F=4.4829, p=0.044)$. Taxonomic distinctness $(\Delta+)$ indices, based on the presence/absence of polychaete species, were exceptionally high in the ANI margin, with an expected $\Delta+$ of 98.7 (range: 92.88-98.77) (Figure 8). The highest $\Delta+$ value was recorded at $50 \mathrm{~m}$ depth of T4 $(300 \mu \mathrm{m}, \mathrm{S} 2)$ where the maximum number of polychaete species was recorded ( 86 species). The lowest $\Delta+$ value was recorded at $200 \mathrm{~m}$ depth of T18 (300 $\mu \mathrm{m}, \mathrm{S} 2)$ where 44 species were recorded.

\section{Polychaete Community Structure}

Multivariate analyses of polychaete species distribution revealed significant bathymetric variations [S1 (500 $\mu \mathrm{m})$ : pseudo$F=2.3536, p=0.001 ; \mathrm{S} 2(300 \mu \mathrm{m}): p$ seudo- $F=2.1056, p=0.001]$ as well as regional distinctions $[\mathrm{S} 1(500 \mu \mathrm{m}):$ pseudo- $F=2.7504$, $p=0.001 ; \mathrm{S} 2(300 \mu \mathrm{m})$ : pseudo- $F=5.0785, p=0.001]$ in both surveys. However, in the non-metric multidimensional scaling (nMDS) the bathymetric variations were superseded by strong the regional distinctions (Figures 9A,B) with two assemblages being readily distinguished - the Andaman Island group (AI) and Nicobar Island group (NI). The biological characteristics of bathymetric and regional assemblages of both surveys are detailed in Tables 4A-C. In S2 $(300 \mu \mathrm{m})$, within the Andaman
Island group (AI), 2 distinct and significant sub-clusters (pseudo$F=4.4266, p=0.001$ ) were formed (Figure 9C), representing the western (WAI) and eastern (EAI) margins. A corresponding distinction was not observed in the Nicobar Islands $(p>0.05)$. The observed regional variations were a result of differences in species composition and relative abundance, as well as the occurrence of rare species.

Predators were the dominant guild in the mesophotic reef areas $(50 \mathrm{~m})$ chiefly represented by syllids, glycerids and eunicids. Deposit feeding polychaetes were highly abundant in the deeper depth strata $(200 \mathrm{~m})$, dominated by spionids, cirratulids, ampharetids (SDF), paraonids, capitellids (SSDF). The contribution of SF (serpulids, sabellids, sabellariids etc.) was very low at all depth strata. Bathymetric variations were prominent in the abundance of predators, but not other feeding groups (Table 3). Significant latitudinal variations in the density of SDF ( $p$ seudo- $F=10.1, p=0.044$ ) and SSDF ( $p$ seudo- $F=86.721$, $p=0.001$ ) was observed only at the $50 \mathrm{~m}$ contour of the AS sector. A SIMPER analysis revealed that deposit feeding sedent polychaetes dominated in the AI group and predatory errant polychaetes dominated in the NI group with 180 species of polychaetes contributing $80 \%(500 \mu \mathrm{m})$ to $83 \%(300 \mu \mathrm{m})$ to dissimilarity. Within the AI group, 231 species of polychaetes contributed $78 \%$ of the dissimilarity between western (WAI) and eastern (EAI) margins. The polychaete species contributing to dissimilarities between the depth categories, regions and margins are presented in Supplementary Tables S6A-I.

\section{Linking Polychaete Distribution to Environmental Conditions}

Bathymetric and regional variation in polychaete species assemblages are well explained by variations in the measured environmental parameters. A canonical correspondence analysis (CCA ordination) elucidated the environmental factors structuring the polychaete communities, based on 50 selected polychaete species. The CCA axis 1 (eigenvalue 0.168 ) and axes 2 (eigenvalue 0.139 ) explained 31.2 and $25.8 \%$ respectively of the variation in the species-environmental relation (Supplementary Table S7A). Axis 1 separated shallow and deeper sites based on bathymetric variations in environmental parameters (temperature, sand, MGZ, clay) while Axis 2 separated sites based on spatial variations in DO, salinity, silt, OM (Figure 10A). The distribution of species that are adapted to specific environmental conditions has been depicted 

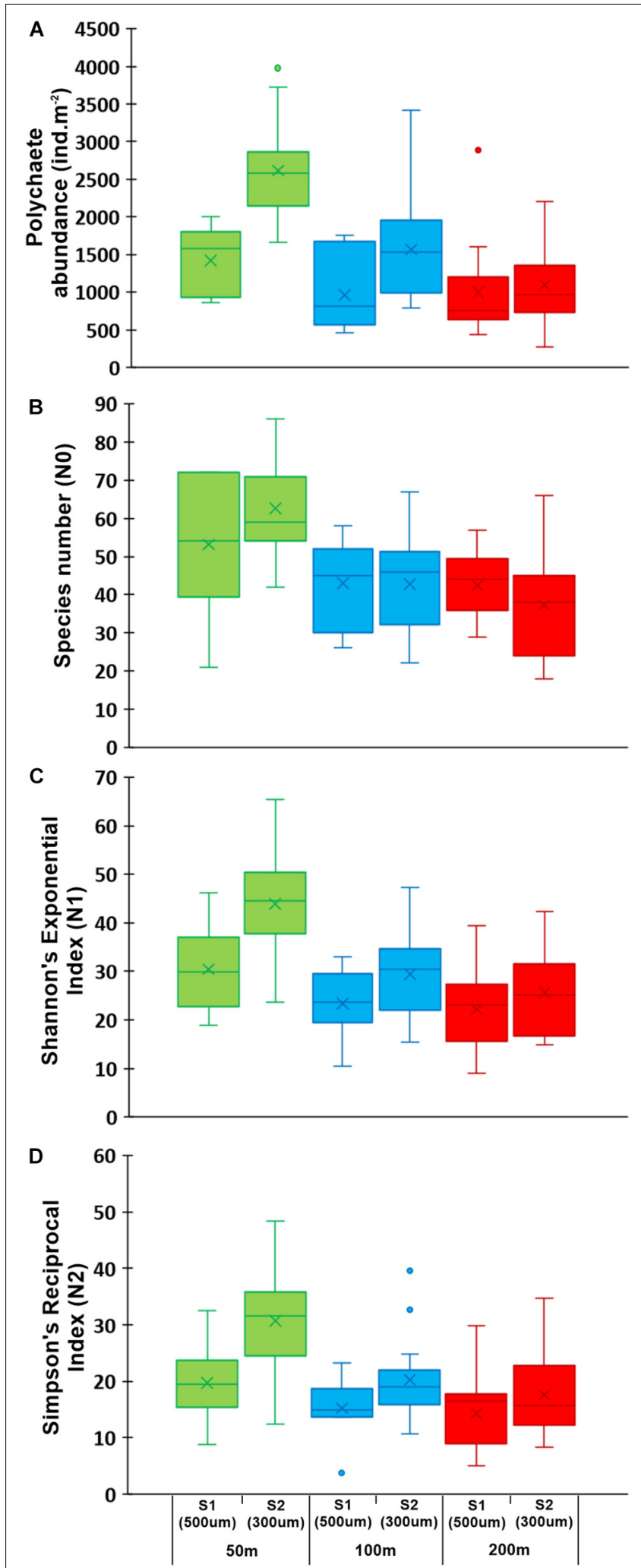

FIGURE 5 | Box-and-whisker plots showing (A) polychaete abundance, (B) species number (N0), (C) Shannon's exponential index (N1), and

(D) Simpson's reciprocal index (N2) at $50 \mathrm{~m}$ (green), $100 \mathrm{~m}$ (blue), and $200 \mathrm{~m}$ (red) depth strata in survey $1(500 \mu \mathrm{m})$ and survey $2(300 \mu \mathrm{m})$. in Figure 10B (Supplementary Table S7B). Predatory errant polychaetes were highly abundant in the $50 \mathrm{~m}$ depth sites, which were characterized by sandy sediments with high DO content. Deposit feeding sedentary polychaetes were abundant in the relatively silty sediments in the $200 \mathrm{~m}$ depth stratum, having relatively low DO. In the intermediate sites $(100 \mathrm{~m})$ both errants and sedent polychaetes were abundant. The density of suspension feeders was low in the study area, with relatively higher values in the mesophotic reef areas. To link the distribution of polychaete feeding guilds with the measured environmental conditions in the study area as a whole, the abundance of feeding guilds (PR, SDF, SSDF, and SF) in each site was superimposed as bubbles on the PCA plot of environmental variables (Figures 11A-D). These figures depict the influence of environmental factors in shaping the above described bathymetric distinctions in the functional diversity of polychaetes.

\section{DISCUSSION}

The Andaman and Nicobar represent a tropical oceanic archipelago in the northern Indian Ocean, which are known for their unique characteristics, from their geology and biodiversity (terrestrial and marine) to their anthropology. The insular margins around these islands are least explored with respect to physical, chemical and biological aspects, particularly in the case of benthic ecosystems. Based on two systematic surveys covering 80 sites ( 23 transects) between 50 and $200 \mathrm{~m}$ depths around the entire island chain $\left(6-14^{\circ} \mathrm{N}\right)$, sampled during north east monsoon (NEM), the present paper provides the first comprehensive picture on the benthic environment, macrozoobenthic standing stock and polychaete community structure around Andaman and Nicobar archipelago.

\section{Environmental Conditions}

The near-bottom hydrographic and sediment characteristics of Andaman and Nicobar waters exhibited significant spatial heterogeneity. Latitudinal variations were significant in the case of DO (at the $200 \mathrm{~m}$ depth stratum), but not in the case of salinity and temperature. Previous studies and concurrent observations report influences from different regions on the physical oceanographic settings around the ANI (Rama Raju et al., 1981; Chandran et al., 2018). The western margin of the Andaman Islands (AI) is influenced by Bay of Bengal waters, the eastern margin by the Ayeyarwady discharge and the waters around the Nicobar Islands (NI) by the intrusion of less saline water from the South China Sea through the Malacca Strait. The variations in seawater temperature and salinity observed in the present study may be attributed to the prevalence of different water-masses at various depths around the ANI. High DO levels ( $>3 \mathrm{ml}^{-1}$ ) in shallow waters (mesophotic reef areas) were evident around the entire ANI (Parulekar and Ansari, 1981). Around the Andaman Islands (north of Ten Degree Channel), oxygen minimum conditions $\left(<0.5 \mathrm{ml} . \mathrm{l}^{-1}\right)$ prevailed in bottom water at $\sim 200 \mathrm{~m}$ depth (Gupta et al., 1981; Ansari and Abidi, 1989; Madhu et al., 2003). However, around the Nicobar Islands, the oxygen minimum conditions occurred at higher 
TABLE 3 | Results of PERMANOVA test for bathymetric variations in macrozoobenthic standing stock, polychaete diversity indices and feeding guilds composition (values in bold indicate statistical significance with $p<0.05$ ).

\begin{tabular}{|c|c|c|c|c|}
\hline \multirow[t]{2}{*}{ Variables } & \multicolumn{2}{|c|}{ Survey $1(500 \mu \mathrm{m})$} & \multicolumn{2}{|c|}{ Survey 2 (300 $\mu \mathrm{m})$} \\
\hline & Pseudo-F & $p$ & Pseudo-F & $p$ \\
\hline Macrozoobenthos density & $F=3.2740$ & $P=0.05$ & $F=15.704$ & $P=0.001$ \\
\hline Macrozoobenthos biomass & $F=1.0661$ & $P=0.37$ & $F=5.9676$ & $P=0.007$ \\
\hline Polychaete density & $F=0.6473$ & $P=0.558$ & $F=4.9929$ & $P=0.011$ \\
\hline Polychaete biomass & $F=0.1892$ & $P=0.872$ & $F=0.9981$ & $P=0.378$ \\
\hline Crustacean density & $F=13.263$ & $P=0.001$ & $F=42.405$ & $P=0.001$ \\
\hline Crustacean biomass & $F=9.1847$ & $P=0.002$ & $F=13.865$ & $P=0.001$ \\
\hline Polychaete species number (NO) & $F=1.2882$ & $P=0.297$ & $F=14.588$ & $P=0.001$ \\
\hline Polychaete Shannon's exponential index (N1) & $F=2.6598$ & $P=0.083$ & $F=15.712$ & $P=0.001$ \\
\hline Polychaete Simpson's reciprocal index (N2) & $F=1.7606$ & $P=0.931$ & $F=12.208$ & $P=0.001$ \\
\hline Predators (PR) & $F=6.7928$ & $P=0.004$ & $F=23.553$ & $P=0.001$ \\
\hline Surface Deposit Feeders (SDF) & $F=3.0783$ & $P=0.055$ & $F=0.5531$ & $P=0.592$ \\
\hline Sub-Surface Deposit Feeders (SSDF) & $F=4.6316$ & $P=0.02$ & $F=2.2752$ & $P=0.119$ \\
\hline
\end{tabular}

( $\sim 220-250 \mathrm{~m}$ ) depths in the present surveys. Along the western margin of the ANI (BoB sector), the massive freshwater influx from major rivers into the Bay of Bengal during the NEM (Sarma et al., 2016) leads to strong, salinity-controlled stratification at the surface, which prevents vertical mixing (Shetye, 1993). These conditions are more clearly observed toward the north, i.e., around the AI (Rama Raju et al., 1981; Thadathil et al., 2002; Chandran et al., 2018). In general, the open ocean oxygen minimum zone (OMZ) of the $\mathrm{BoB}$ is reported to occur between 91 and $582 \mathrm{~m}$ (Helly and Levin, 2004), and is known to impinge on the ANI margin (Parulekar and Ansari, 1981). Along the eastern margin of the ANI (AS sector), the stratification due to Ayeyarwady discharge (Chandran et al., 2018) may be the main reason for oxygen minimum conditions, along with the presence of shallow sills in the Andaman Sea, which hinders water exchange (Gupta et al., 1981). Along the BoB and AS sectors, the oxygen minimum conditions were found to intensify toward the north (Garg et al., 1968; Nair and Gireesh, 2010), even reaching up to the $100 \mathrm{~m}$ depth stratum in the northern transects of the $\mathrm{BoB}$ sector (from $12^{\circ} \mathrm{N}$ ) during the present surveys.

The ANI are volcanic in origin, with steep insular margins (Rao and Kessarkar, 2001). The shelf is reported to be wider (Rao and Kessarkar, 2001) along the western side (10-50 km), when compared to the east $(<10 \mathrm{~km})$. Fringing coral reefs occur up to $50-75 \mathrm{~m}$ depths around the archipelago, with a $<500 \mathrm{~m}$ wide reef flat (UNEP/IUCN, 1988; Bahuguna and Nayak, 1998; Brown, 2005; Mahendra et al., 2010; Velloth et al., 2014). The coral reefs influence the surficial sediments in the study area. Biogenic coarser sediment (composed mainly of eroded coral fragments, coralline sand, sponge spicules, etc.) dominate in the shallow (50 m) depths (Parulekar and Ansari, 1981), owing to the proximity to mesophotic reefs. As the depth increased (to $200 \mathrm{~m}$ ) in the ANI margin, the sediment texture gradually changed to sandy silt (Parulekar and Ansari, 1981), which was more prominent around the Andaman Islands. This is attributed sediment discharge from the Ayeyarwady River, along with the seasonally reversing circulation patterns in the Andaman
Sea (Rodolfo, 1969; Wyrtki, 1973; Ramaswamy et al., 2004; Rao et al., 2005). Around the Nicobar Islands, coral derived sediments were present, even further away from the reefs (200 m). Strong bottom currents have been reported around the entire archipelago, and are stronger around the disjointed islands of the Nicobar (Chandran et al., 2018). Strong currents are known to re-suspend and sort bottom sediments, resulting in coarsegrained beds composed of sand to granule-size, loose carbonate materials (Li and Amos, 1999). The steep depth gradients in the ANI margin facilitate the transport of finer particles to higher depths (Hashimi et al., 1981), and result in settlement in the less dynamic, deeper areas.

The waters around the ANI are known to be oligotrophic (Ansari and Abidi, 1989; Sarupria and Bhargava, 1993). Observations from the present study, of low (0.05-3.90\%) organic matter (OM), may be attributed to this, as opposed to the productive continental margins of the northern Indian Ocean (Ganesh and Raman, 2007; Joydas and Damodaran, 2009). The OM content in the study area correlated strongly with the proportion of finer sediment fractions (Keil et al., 1994), with low $\mathrm{OM}$ in the coralline sands of the mesophotic reef areas $(50 \mathrm{~m})$ and higher OM content in relatively silty sediments of the deeper strata $(200 \mathrm{~m})$. Compared to the Andaman Islands, OM content around the Nicobar Islands was significantly lower, indicating that in high energy environments with strong water currents, the advective transport of particulates through porous sediments will be higher, hindering the deposition of OM on the sediment surface (Alongi et al., 1996).

\section{Macrozoobenthic Communities}

Studies on standing stock of macrozoobenthos around oceanic islands of the tropical belt are mainly confined to reef areas, beyond which studies are scarce. The present study is based on two surveys (beyond $50 \mathrm{~m}$ depth), which used different sample sizes and mesh sizes. The influence of these methodological differences on the results are elaborated in the "Methods Discussion" section below. Overall, latitudinal variations in 


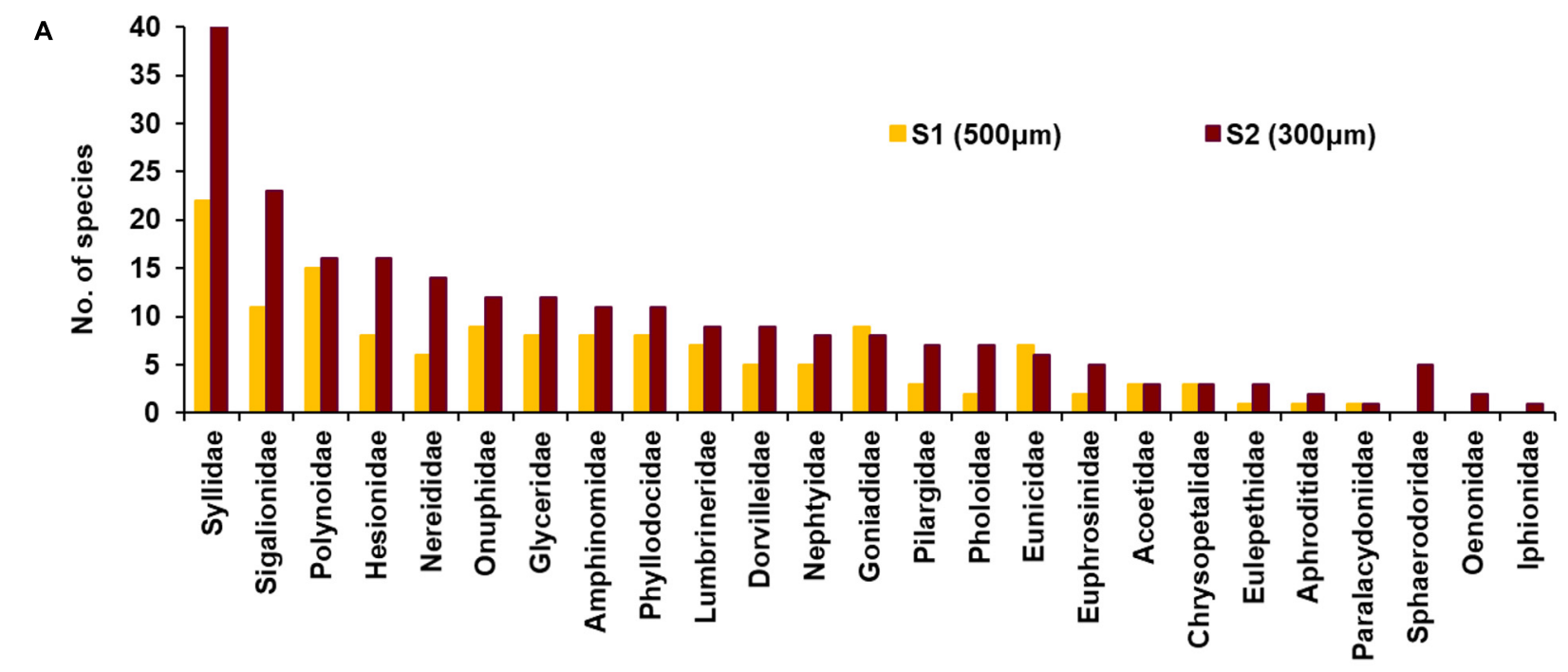

B

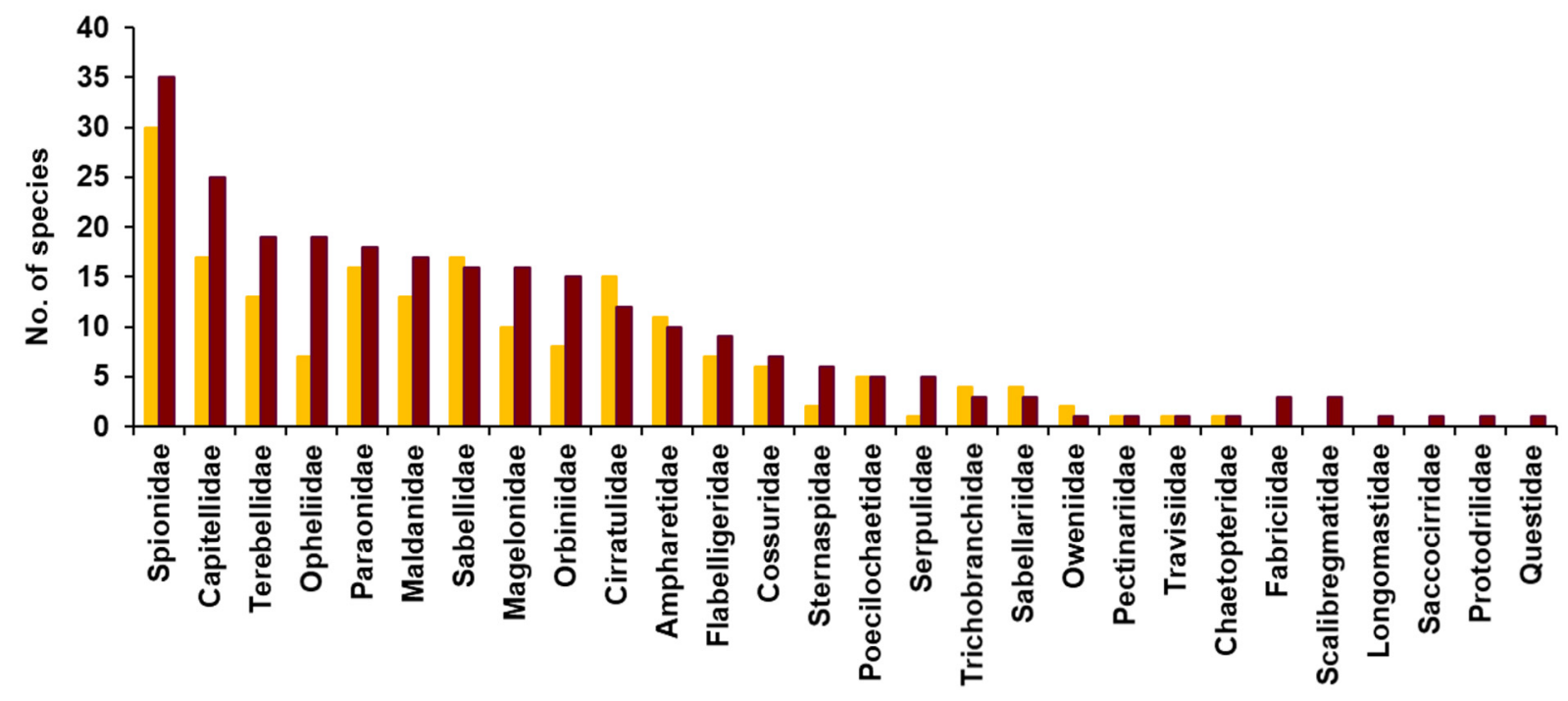

FIGURE 6 | Number of polychaete species represented among polychaete families, (A) Errantia and (B) Sedentaria in survey 1 (S1, yellow bars, $500 \mu \mathrm{m})$ and survey 2 (S2, maroon bars, $300 \mu \mathrm{m}$ ).

density and biomass of macrozoobenthos were not significant. Both density and biomass showed a gradual decrease from shallow to deeper areas in both surveys. Similar decreasing trends in standing stock of macrozoobenthos with increasing depth have been reported from the earlier studies around the Andaman and Nicobar archipelago (Parulekar and Ansari, 1981). In the ANI margin, the standing stock was relatively low compared to other highly productive continental margins of the adjacent areas (Supplementary Table S8) in the northern Indian Ocean (Chatananthawej and Bussarawit, 1987; Ganesh and Raman, 2007; Joydas and Damodaran, 2009; Damodaran, 2010; Ansari et al., 2012; Manokaran et al., 2015).

As commonly observed in other soft-bottom sediments around the world, polychaetes were the dominant group at all depths in the ANI margin (Parulekar and Ansari, 1981). High densities of polychaetes and crustaceans were observed in the mesophotic areas $(50 \mathrm{~m})$, particularly in the finer sieve (300 $\mu \mathrm{m}, \mathrm{S} 2)$. The present observations suggest that small-sized interstitial taxa among polychaetes and crustaceans were well suited to the well oxygenated, coralline sandy sediments of the mesophotic reef areas, characterized by large grain sized particles with enough interstitial spaces (McCarthy et al., 2000; Kramer et al., 2014; Narayanaswamy et al., 2017). The availability of smallsized prey organisms in the sediment interstices supported the high density of predatory crustaceans, particularly amphipods (Riddle, 1988; Preston and Doherty, 1994; Navarro-Barranco and Guerra-García, 2016). At the $200 \mathrm{~m}$ stratum, the relatively oxygenated $(\mathrm{DO}>0.5 \mathrm{ml} / \mathrm{l})$ sandy sediments of the Nicobar Islands harbored higher densities of crustaceans when compared to oxygen deficient $(\mathrm{DO}<0.5 \mathrm{ml} / \mathrm{l})$, sandy silt sediments of the Andaman Islands (Karakassis and Eleftheriou, 1997; Levin and Gage, 1998). The latter region was characterized by the 


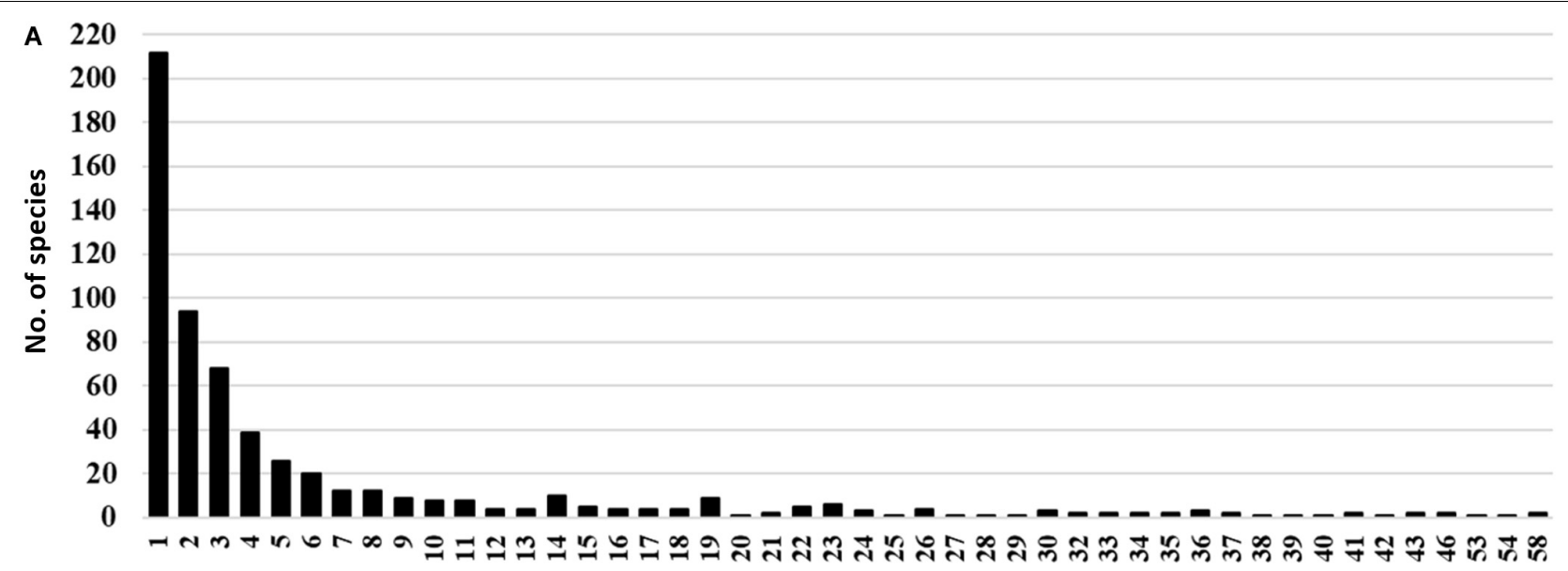

B

No. of sites at which species occurred

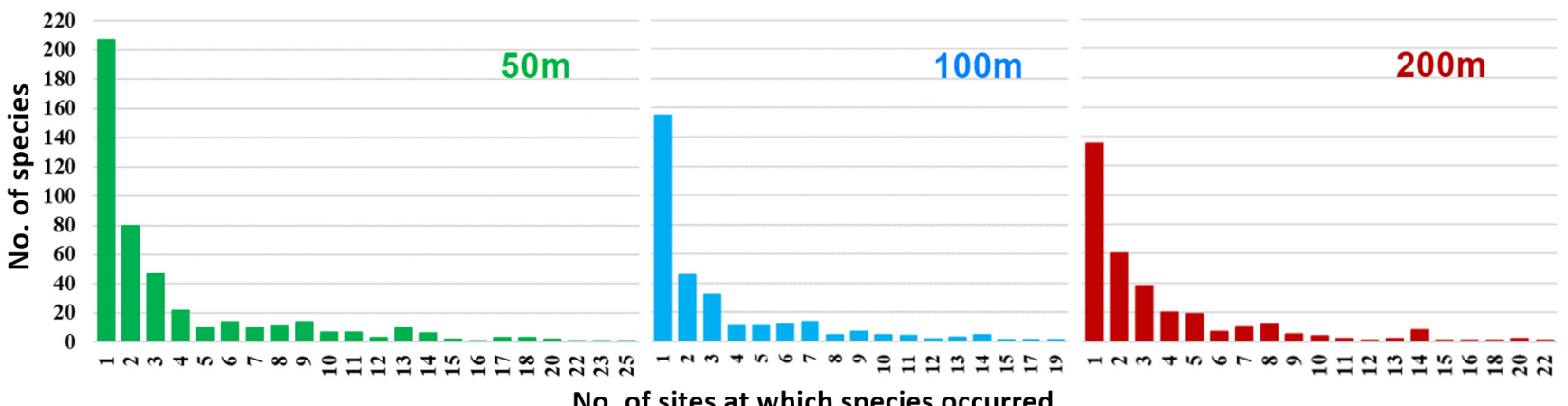

No. of sites at which species occurred

FIGURE 7 | Proportion of rare polychaete species based on number of species ( $y$ axis) occurring at exactly $n$ sites ( $x$ axis), (A) in the entire study area (black bars), and (B) at $50 \mathrm{~m}$ (green bars), $100 \mathrm{~m}$ (blue bars), and $200 \mathrm{~m}$ (red bars) depth strata.

dominance of polychaetes (91\%), under the OMZ conditions (Abdul Jaleel et al., 2014; Joydas and Damodaran, 2014; Raman et al., 2015; Khan et al., 2017). Echinoderms, which are most vulnerable to oxygen depleted conditions (Diaz and Rosenberg, 1995; Parameswaran et al., 2018), were altogether absent in the oxygen deficient conditions prevailing at $\sim 200 \mathrm{~m}$ depth around the Andaman Islands.

\section{Polychaete Diversity and Communities}

Studies on polychaete diversity in the ANI have been restricted mainly to shallow reef areas ( $<30 \mathrm{~m}$ depth) with 224 reported species (Rajasekaran and Fernando, 2012; Rajasekaran, 2015; Lakra et al., 2018). The present study from mesophotic reef areas $(50-200 \mathrm{~m})$ records a total of 606 species, including three new species (Gopal et al., 2014, 2016, 2020) and rediscoveries of rare and poorly known taxa (e.g., Palmyreuphrosyne sp., Imajimapholoe sp., Hartmanipsammolyce sp.). This study adds 551 species to the regional inventory, and the polychaete diversity around the ANI is updated to 775 species.

In the ANI margin, polychaetes having limited occurrence (singletons and doubletons) accounted for $50 \%$ of the diversity. High proportions of rare species have also been reported in the macrozoobenthic communities around the Ningaloo Reef, Australia (Przeslawski et al., 2013). The proportion of rare species was higher around mesophotic reefs (50 $\mathrm{m}$ depth) in the ANI margin. These observations illustrate the rich biodiversity harbored in the ANI margin, having a high degree of rarity with respect to abundance and distribution range (Gaston, 1994; Ellingsen et al., 2007), especially in the mesophotic reef areas $(50 \mathrm{~m})$. The rarity of species, along with the variation in relative abundance of common species, contributed to marked regional distinctions in polychaete assemblages in the study area. These distinctions, therefore, were not evident in the univariate indices $(\mathrm{N} 0, \mathrm{~N} 1, \mathrm{~N} 2)$ alone $(p>0.05)$. Three regions could be distinguished in the ANI margin - the western margin of the Andaman Islands, the eastern margin of the Andaman Islands and the Nicobar Islands. The exceptionally high number of rare species and diversity of polychaetes around the archipelago might be due to its geographical positioning at the juncture between two biogeographic regions (Sibaja-Cordero et al., 2016). The seas around the archipelago are land-locked to the north and east (i.e., Andaman sector). The continuous island mass of the Andaman restricts circulation between the Andaman Sea basin and the Bay of Bengal basin, which are connected only through the Preparis Channel to the north and the Ten Degree Channel to the south. By contrast, the southern part of the archipelago (i.e., the Nicobar Islands) is largely open to the north eastern Indian Ocean to the west and to the South 


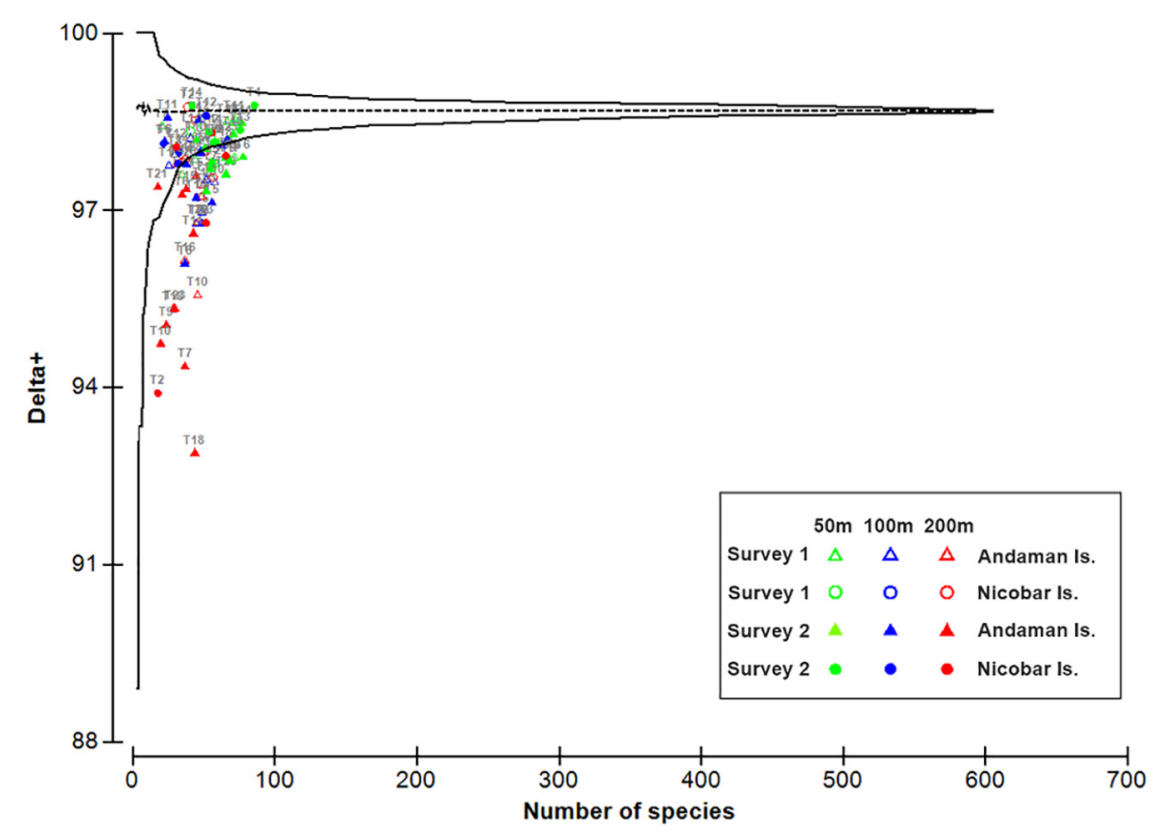

FIGURE 8 | Taxonomic funnel plot depicting number of polychaete species ( $x$ axis) against the taxonomic distinctness index ( $\Delta+)(y$ axis), with $95 \%$ probability funnel based on the master taxonomic tree in each site at $50 \mathrm{~m}$ (green), $100 \mathrm{~m}$ (blue), and $200 \mathrm{~m}$ (red) depth strata in survey 1 (hollow symbols) and survey 2 (filled symbols).

China Sea on the east, through the Malacca Strait. The channels that separate the Nicobar Islands permit continuous circulation between the southern Bay of Bengal and Andaman Sea (Rao and Kessarkar, 2001). High polychaete diversity is reported along the eastern margin of the Andaman Sea, off western Thailand (Bussarawit et al., 2008), and the Coral Triangle (Philippines to the Solomon Islands) is a hotspot of marine diversity (Veron et al., 2009). The circulation of water within the Andaman Sea and through the Malacca Strait (Chandran et al., 2018) would result in periodic exchange of polychaete larvae with these highdiversity areas (Carson and Hentschel, 2006; Pilditch et al., 2015). The comparable environmental settings of the study area would favor settlement and survival of these larvae, which in turn is dependent on currents and oceanographic processes (Parker and Tunnicliffe, 1994; Largier, 2003; Qian and Dahms, 2005). This could be a major factor causing high diversity and the occurrence of rare species around the island ecosystem (Riddle, 1988).

The regional distinctions in polychaete communities were clearly reflected in their functional (feeding guild) composition. The establishment of different species in an area having almost similar morphological traits demonstrates that habitat-related factors exert a major role in structuring polychaete assemblages (Otegui et al., 2016). The proportion of predatory polychaetes was higher in the Nicobar Islands at all depths, when compared to the Andaman. This is attributed to availability of prey organisms in the interstices of the coralline sand of this region, with ample oxygen availability. The sediments around the Andaman Islands, on the other hand, were relatively silty in nature with higher OM content, and therefore harbored a higher percentage of deposit feeding forms. Within the Andaman Islands, the proportion of deposit feeders (sedents) was higher along the east coast, which correlates with the higher proportion of silt and OM in this region. The aforementioned strong regional distinctions in polychaete assemblages overrode the universally observed bathymetric trends in diversity and community structure.

During the present study, highest polychaete diversity was recorded in the mesophotic reef areas (50 $\mathrm{m}$ depth), which decreased marginally with increasing depth in both the Andaman and Nicobar regions. The decrease in polychaete diversity with increasing depth is a conspicuous feature in other parts of the northern Indian Ocean (Ganesh and Raman, 2007; Joydas and Damodaran, 2009; Manokaran et al., 2015). The poorly sorted coralline sand with coral rubble, gravel, shells, spicules etc., in the mesophotic areas provided enough microhabitats and food for predatory polychaetes, and therefore harbored high diversity of this guild (McCarthy et al., 2000). Syllids, which were the most abundant and species-rich taxon in the mesophotic reef areas, are relatively small, highly motile predatory forms, capable of occupying the interstitial spaces of the coarse sediments (Riddle, 1988; Martins et al., 2013). Other active predators like scale worms, nereids, eunicids, onuphids and glycerids, which are known to prefer well-oxygenated coarse sandy sediments (Hutchings, 1998), were similarly well represented at this depth. High abundance of predators is known to be accompanied with high environmental quality (Cheung et al., 2008). In the mesophotic reef areas, the percentage of sub-surface deposit feeders in the coarser sediments was very low, as the presence of dead shell pieces, sponge spicules, coral fragments etc. interrupt their feeding (de Paiva, 1993; Pagliosa, 2005). Tube dwelling suspension feeders like sabellids, serpulids, oweniids 


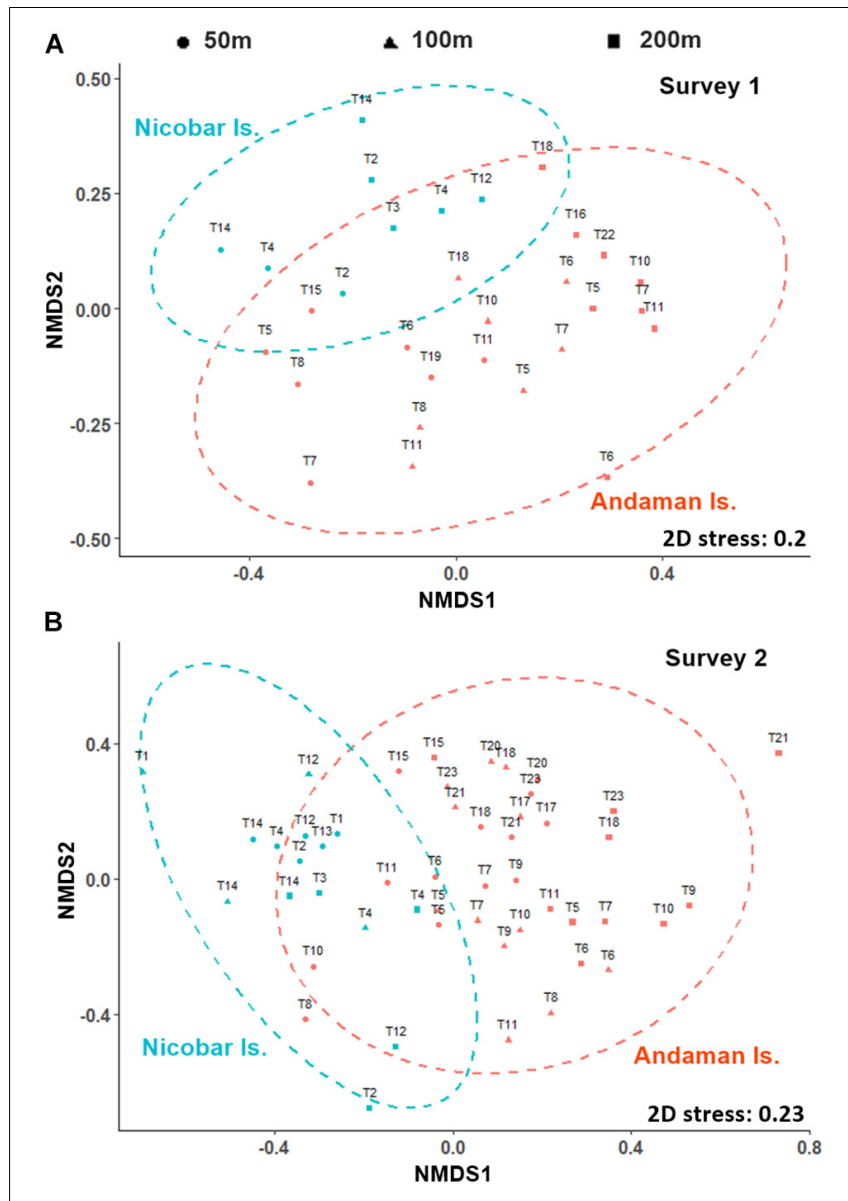

C

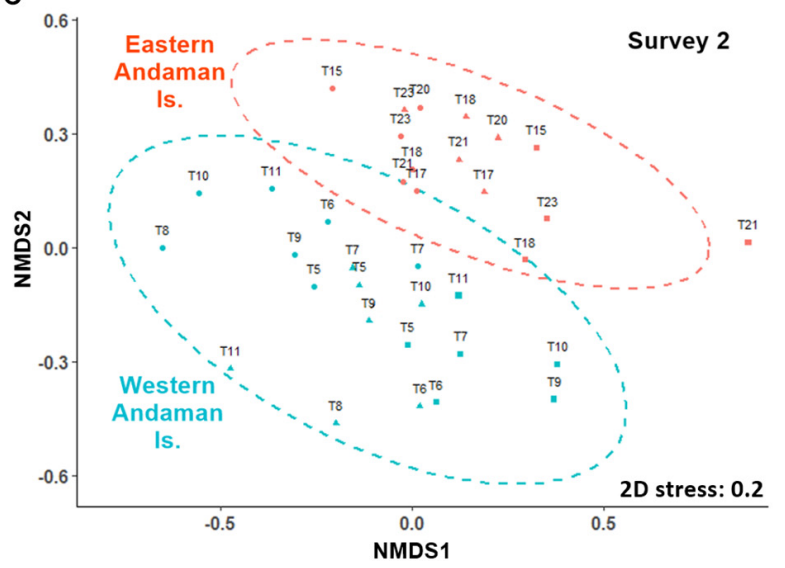

FIGURE 9 | Non-metric multi-dimensional scaling (nMDS) plots of polychaete species data (based on the Bary-Curtis similarity matrix of the square root transformed data) showing regional distictions among, (A) Andaman (orange) and Nicobar (blue) Island groups in survey $1(500 \mu \mathrm{m})$, (B) among Andaman (orange) and Nicobar Island (blue) groups in survey 2 (300 $\mu \mathrm{m}$, and (C) among eastern (orange) and western (blue) margins of Andaman Islands in S2 $(300 \mu \mathrm{m})(\bullet 50 \mathrm{~m}$ sites, $\boldsymbol{\Delta} 100 \mathrm{~m}$ sites, and $200 \mathrm{~m}$ sites).

and pectinariids were well represented at this depth where raw materials for building tubes were plentiful (Narayanaswamy et al., 2017). They were able to take advantage of the hydrodynamically active conditions prevailing in the region, which favour the resuspension of OM to the water column (Dolbeth et al., 2009). Errant species like Micronephtys sphaerocirrata, Syllis cornuta, Chrysopetalum maculata, Eunice indica, Glycera spp. and Lumbrineris meteorana showed affinity to the environmental conditions prevailing in mesophotic reef areas. Within the $50 \mathrm{~m}$ depth strata in the Andaman region, variations in sediment texture led to polychaete community level distinctions between the eastern and western margins. Higher proportion of fine sediments along the eastern margin favored deposit feeders like Prionospio andamanensis, Notomastus aberans, and Ampharete agulhasensis. Along the western margin, the relative proportion of predators was higher, as fine sediments were restrained to localized sites (T6 and T7).

In the ANI margin, a progressive increase in depth (and distance from reefs) was associated with an increase in the relative proportion of silt and $\mathrm{OM}$, with sediment texture changing from sand $(50 \mathrm{~m})$ to sandy silt $(200 \mathrm{~m})$, and this was coupled with a marked decline in DO. These trends were more prominent in the Andaman Islands, where OMZ conditions $\left(<0.5 \mathrm{ml} . \mathrm{l}^{-1}\right)$ were encountered at 150-200 m depths. High densities of spionids, cirratulids, paraonids and ampharetids were found in this region (Ingole et al., 2010; Abdul Jaleel et al., 2014; Joydas and Damodaran, 2014; Raman et al., 2015) chiefly represented by Prionospio spp., Kirkegaardia dorsobranchialis, Aricidea lopezi, Levinsenia oculata etc. These are among the genera most commonly encountered in OMZ settings in other parts of the world (Lamont and Gage, 2000; Levin, 2003), which is attributed to their extensive branchiae, and deposit feeding life mode (Abdul Jaleel et al., 2014). Abundance of predators decreased by $57-70 \%$ toward deeper sites as the bottom nature changed to sandy silt, and the limited sediment pore size formed a barrier for interstitial organisms to thrive. When compared to the Andamans, the relative composition of predators was 1.3 times higher in the deeper areas of the Nicobar Islands (DO $\left.>0.5 \mathrm{ml} . \mathrm{l}^{-1}\right)$, and errants were also well represented. The characteristic species in this region were Goniada maculata, Prionospio spp., Sigambra parva, Notomastus aberans, Glycera spp., Eunice indica and Ampharete spp.

The steep slope of the ANI margin, with a sharp increase in depth from 50 to $200 \mathrm{~m}$ within a relatively short distance ( $<10$ nautical miles), facilitates the transport of finer sediment particles and OM toward the deeper areas via turbidity flows (Abdul Jaleel et al., 2014). A major portion of the available OM is kept in suspension in the benthic boundary layer. Spionids and cirratulids are known to adapt to ambient conditions by switching feeding modes between deposit feeding and suspension feeding, in response to flow and sediment transport regimes (Fauchald and Jumars, 1979; Dauer et al., 1981). These taxa may be utilizing the OM available not only within the sediments but also in the sediment-water interphase. While the present study noted OMZ conditions at $200 \mathrm{~m}$ depth around the Andaman Islands, polychaete diversity was significantly higher than other OMZ-impacted margins around the world. This is a result of the occurrence of sedentarian taxa such as Ampharete agulhasensis, Levinsenia gracilis, Prionospio spp., Tharyx annulosus with low dominance, in contrast to other OMZ-margins (Levin, 2003; 
TABLE 4A | Biological characteristics of polychaete species assemblages in Survey $1(500 \mu \mathrm{m})$ with prevailing environmental conditions [mean \pm SD, $n=$ No. of samples].

\begin{tabular}{|c|c|c|c|c|c|c|}
\hline \multirow{3}{*}{$\begin{array}{l}\text { Survey: } \\
\text { Depth: } \\
\text { Region: }\end{array}$} & \multicolumn{6}{|c|}{ Survey $1(500 \mu \mathrm{m})$} \\
\hline & \multicolumn{2}{|c|}{$50 \mathrm{~m}$} & \multicolumn{2}{|c|}{$100 \mathrm{~m}$} & \multicolumn{2}{|c|}{$200 \mathrm{~m}$} \\
\hline & Andaman Is. $(n=7)$ & Nicobar Is. $(n=3)$ & Andaman Is. $(n=7)$ & Nicobar Is.* & Andaman Is. $(n=8)$ & Nicobar Is. $(n=5)$ \\
\hline Temperature $\left({ }^{\circ} \mathrm{C}\right)$ & $27.77 \pm 0.30$ & $27.22 \pm 0.56$ & $26.20 \pm 1.45$ & $24.29 \pm 2.62$ & $13.96 \pm 0.65$ & $14.39 \pm 0.81$ \\
\hline Salinity & $32.92 \pm 0.43$ & $33.19 \pm 0.32$ & $33.83 \pm 0.39$ & $33.99 \pm 0.44$ & $34.95 \pm 0.03$ & $34.90 \pm 0.04$ \\
\hline $\begin{array}{l}\text { Dissolved oxygen } \\
\left(\mathrm{ml} . \mathrm{I}^{-1}\right)\end{array}$ & $4.03 \pm 0.16$ & $3.68 \pm 0.29$ & $2.62 \pm 0.72$ & $2.63 \pm 0.80$ & $0.31 \pm 0.14$ & $0.65 \pm 0.06$ \\
\hline Sand (\%) & $15.07-98.15$ & $95.14-100$ & $47.78-93.61$ & $90.68-100$ & $1.52-77.71$ & $51.94-98.97$ \\
\hline Silt (\%) & $1.54-78.35$ & $0-3.46$ & $1.81-42.84$ & $0-1.37$ & $13.51-70.80$ & $0.85-24.86$ \\
\hline Clay (\%) & $0.31-6.58$ & $0-1.41$ & $4.57-14.76$ & $0.24-0.42$ & $8.78-27.68$ & $0.17-45.95$ \\
\hline Organic matter (\%) & $0.88 \pm 0.60$ & $0.34 \pm 0.12$ & $0.85 \pm 0.31$ & $0.32 \pm 0.09$ & $1.34 \pm 1.04$ & $0.48 \pm 0.16$ \\
\hline Abundance (ind. $\mathrm{m}^{-2}$ ) & $600 \pm 238$ & $530 \pm 194$ & $622 \pm 423$ & - & $750 \pm 371$ & $879 \pm 864$ \\
\hline $\begin{array}{l}\text { Wet weight biomass } \\
\left(\mathrm{g} \cdot \mathrm{m}^{-2}\right)\end{array}$ & $2.84 \pm 1.61$ & $2.43 \pm 1.03$ & $2.61 \pm 2.16$ & - & $3.03 \pm 1.75$ & $3.15 \pm 3.44$ \\
\hline Species number (NO) & $55 \pm 21$ & $50 \pm 9$ & $43 \pm 12$ & - & $43 \pm 9$ & $43 \pm 9$ \\
\hline $\begin{array}{l}\text { Shannon's exponential } \\
\text { index (N1) }\end{array}$ & $33.51 \pm 8.65$ & $23.35 \pm 4.20$ & $23.45 \pm 7.27$ & - & $20.06 \pm 7.58$ & $25.49 \pm 8.75$ \\
\hline $\begin{array}{l}\text { Simpson's reciprocal } \\
\text { index (N2) }\end{array}$ & $22.66 \pm 5.40$ & $12.95 \pm 3.80$ & $15.24 \pm 6.01$ & - & $11.97 \pm 5.14$ & $17.97 \pm 7.51$ \\
\hline Predators (\%) & 55 & 67 & 23 & - & 9 & 31 \\
\hline $\begin{array}{l}\text { Surface deposit feeders } \\
(\%)\end{array}$ & 28 & 23 & 54 & - & 57 & 41 \\
\hline $\begin{array}{l}\text { Sub-surface deposit } \\
\text { feeders (\%) }\end{array}$ & 14 & 6 & 20 & - & 31 & 12 \\
\hline Suspension feeders (\%) & 2 & 4 & 3 & - & 3 & 17 \\
\hline $\begin{array}{l}\text { Similarity causing } \\
\text { species (contributing } \\
\text { more than 5\%) }\end{array}$ & $\begin{array}{c}\text { Notomastus aberans } \\
\text { (7.6\%), Eunice indica } \\
(6.63 \%), \text { Aonidella dayi } \\
\text { (6.58\%), Nereis spp. } \\
\text { (6.02\%) }\end{array}$ & $\begin{array}{l}\text { Glycera spp. (17\%), } \\
\text { Syllis cornuta (14.59\%), } \\
\text { Syllis spp. }(9.04 \%), \\
\text { Eunice indica (6.73\%) }\end{array}$ & $\begin{array}{c}\text { Aonidella dayi } \\
\text { (13.22\%), Prionospio } \\
\text { cirrifera (7.30\%), } \\
\text { Aricidea spp. (5.56\%), } \\
\text { Notomastus aberans } \\
(5.08 \%)\end{array}$ & - & $\begin{array}{c}\text { Levinsenia oculata } \\
(9.03 \%), \text { Aricidea lopezi } \\
(8.63 \%), \text { Kirkegaardia } \\
\text { dorsobranchialis } \\
\text { (8.45\%), Prionospio } \\
\text { spp. (5.44\%) }\end{array}$ & $\begin{array}{c}\text { Notomastus aberans } \\
(9.24 \%), \text { Goniada } \\
\text { maculata (8.12\%), } \\
\text { Prionospio spp. } \\
\text { (7.59\%), Sigambra } \\
\text { parva }(7.05 \%)\end{array}$ \\
\hline
\end{tabular}

*Percentage of sediment in grab samples were less (<50\%) for biological analysis at all $100 \mathrm{~m}$ depth sites in the Nicobar Islands during Survey 1. 
TABLE 4B | Biological characteristics of the polychaete species assemblages in Survey $2(300 \mu \mathrm{m})$ with prevailing environmental conditions [mean \pm SD, $n=$ No. of samples]

\begin{tabular}{|c|c|c|c|c|c|c|}
\hline \multirow{3}{*}{$\begin{array}{l}\text { Survey: } \\
\text { Depth: } \\
\text { Region: }\end{array}$} & \multicolumn{6}{|c|}{ Survey $2(300 \mu \mathrm{m})$} \\
\hline & \multicolumn{2}{|c|}{$50 \mathrm{~m}$} & \multicolumn{2}{|c|}{$100 \mathrm{~m}$} & \multicolumn{2}{|c|}{$200 \mathrm{~m}$} \\
\hline & Andaman Is. $(n=13)$ & Nicobar Is. $(n=6)$ & Andaman Is. $(n=12)$ & Nicobar Is. $(n=4)$ & Andaman Is. $(n=10)$ & Nicobar Is. $(n=5)$ \\
\hline Temperature $\left({ }^{\circ} \mathrm{C}\right)$ & $27.21 \pm 0.80$ & $27.34 \pm 0.77$ & $21.49 \pm 1.60$ & $20.43 \pm 0.89$ & $13.82 \pm 0.78$ & $14.06 \pm 1.00$ \\
\hline Salinity & $33.46 \pm 0.43$ & $33.56 \pm 0.38$ & $34.54 \pm 0.11$ & $34.56 \pm 0.15$ & $34.95 \pm 0.04$ & $34.92 \pm 0.03$ \\
\hline $\begin{array}{l}\text { Dissolved oxygen } \\
\left(\mathrm{ml} . \mathrm{I}^{-1}\right)\end{array}$ & $3.11 \pm 0.63$ & $3.66 \pm 0.33$ & $0.79 \pm 0.38$ & $1.36 \pm 0.09$ & $0.27 \pm 0.08$ & $0.60 \pm 0.08$ \\
\hline Sand (\%) & $15.07-99.05$ & $98.93-100$ & $34.73-100$ & $90.68-100$ & $1.85-98.05$ & $60.88-98.97$ \\
\hline Silt (\%) & $0.79-78.35$ & $0-0.89$ & $0-43.62$ & $0-7.95$ & $1.62-67.96$ & $0.85-34.24$ \\
\hline Clay (\%) & $0.16-11.93$ & $0-0.18$ & $0-21.65$ & $0-1.37$ & $0.32-30.19$ & $0.17-7.57$ \\
\hline Organic matter (\%) & $0.75 \pm 0.38$ & $0.31 \pm 0.11$ & $0.69 \pm 0.29$ & $0.24 \pm 0.18$ & $2.17 \pm 0.99$ & $0.45 \pm 0.31$ \\
\hline Abundance (ind. -2) $^{-2}$ ) & $1558 \pm 519$ & $1318 \pm 332$ & $1200 \pm 395$ & $842 \pm 481$ & $887 \pm 547$ & $1028 \pm 605$ \\
\hline $\begin{array}{l}\text { Wet weight biomass } \\
\left(\mathrm{g} \cdot \mathrm{m}^{-2}\right)\end{array}$ & $2.71 \pm 0.70$ & $2.08 \pm 0.73$ & $2.83 \pm 1.54$ & $2.27 \pm 2.21$ & $2.13 \pm 1.37$ & $2.57 \pm 2.21$ \\
\hline Species number (NO) & $63 \pm 10$ & $63 \pm 16$ & $45 \pm 14$ & $35 \pm 13$ & $34 \pm 10$ & $45 \pm 20$ \\
\hline $\begin{array}{l}\text { Shannon's exponential } \\
\text { index (N1) }\end{array}$ & $42.31 \pm 8.96$ & $47.26 \pm 12.59$ & $31.59 \pm 8.84$ & $23.00 \pm 6.37$ & $23.41 \pm 6.36$ & $29.98 \pm 13.08$ \\
\hline $\begin{array}{l}\text { Simpson's reciprocal } \\
\text { index (N2) }\end{array}$ & $28.86 \pm 8.78$ & $34.79 \pm 9.35$ & $21.83 \pm 7.39$ & $15.67 \pm 4.31$ & $16.64 \pm 4.63$ & $19.54 \pm 10.53$ \\
\hline Predators (\%) & 42 & 63 & 34 & 73 & 16 & 38 \\
\hline $\begin{array}{l}\text { Surface deposit feeders } \\
\text { (\%) }\end{array}$ & 36 & 16 & 44 & 16 & 49 & 32 \\
\hline $\begin{array}{l}\text { Sub-surface deposit } \\
\text { feeders (\%) }\end{array}$ & 20 & 13 & 18 & 10 & 31 & 25 \\
\hline Suspension feeders (\%) & 3 & 7 & 4 & 2 & 3 & 5 \\
\hline $\begin{array}{l}\text { Similarity causing } \\
\text { species (contributing } \\
\text { more than 5\%) }\end{array}$ & $\begin{array}{c}\text { Micronephtys } \\
\text { sphaerocirrata (5.72\%), } \\
\text { Aonidella spp. (5.59\%) }\end{array}$ & $\begin{array}{c}\text { Glycera lapidum } \\
(6.99 \%), \text { Syllis cornuta } \\
(6.58 \%)\end{array}$ & $\begin{array}{c}\text { Spipophanes spp. } \\
(11.98 \%)\end{array}$ & $\begin{array}{c}\text { Glycera lapidum } \\
\text { (10.21\%), Syllis cornuta } \\
\text { (8.01\%), Glycera } \\
\text { benguellana (7.21\%), } \\
\text { Protodorvillea egena } \\
\text { (6.36\%), Syllis spp. } \\
(6.30 \%)\end{array}$ & $\begin{array}{c}\text { Prionospio (Minuspio) } \\
\text { spp. (11.16\%), } \\
\text { Kirkegaardia } \\
\text { dorsobranchialis } \\
\text { (7.95\%), Prionospio } \\
\text { spp. (6.78\%), } \\
\text { Spiophanes spp. } \\
\text { (6.04\%), Aricidea lopezi } \\
\text { (5.59\%) }\end{array}$ & $\begin{array}{c}\text { Aricidea catherinae } \\
\text { (8.95\%), Aricidea spp. } \\
\text { (6.55\%), Amphicteis } \\
\text { gunneri (6.16\%), } \\
\text { Spiophanes spp. } \\
(5.03 \%), \text { Sigambra } \\
\text { parva }(5.00 \%)\end{array}$ \\
\hline
\end{tabular}


TABLE 4C | Biological characteristics of the polychaete species assemblages along western (WAl) and eastern (EAl) margins of the Andaman Islands in Survey 2 (300 $\mu \mathrm{m}$ ) with prevailing environmental conditions [mean $\pm \mathrm{SD}, n=$ No. of samples].

$\begin{array}{ll}\text { Survey: } & \text { Survey } 2(300 \mu \mathrm{m})\end{array}$

\section{Region/Sector:}

Depth:

Temperature $\left({ }^{\circ} \mathrm{C}\right)$

Salinity

Dissolved oxygen

(ml..$^{-1}$ )

Sand (\%)

Silt (\%)

Clay (\%)

Organic matter (\%)

Abundance (ind. $\mathrm{m}^{-2}$ )

Wet weight biomass

(g.m ${ }^{-2}$ )

Species number (NO)

Shannon's exponential

index (N1)

Simpson's reciprocal

index (N2)

Predators (\%)

Surface deposit feeders

(\%)

Sub-surface deposit

feeders (\%)

Suspension feeders (\%)

Similarity causing

species (contributing

more than $5 \%$

\begin{tabular}{|c|c|c|c|}
\hline \multicolumn{3}{|c|}{ Western margin of Andaman Is. } & \multirow[b]{2}{*}{$50 \mathrm{~m}(n=6)$} \\
\hline $50 \mathrm{~m}(n=7)$ & $100 \mathrm{~m}(n=7)$ & $200 \mathrm{~m}(n=6)$ & \\
\hline $27.33 \pm 0.61$ & $22.36 \pm 1.38$ & $13.66 \pm 0.50$ & $27.08 \pm 1.02$ \\
\hline $33.67 \pm 0.34$ & $34.58 \pm 0.12$ & $34.97 \pm 0.02$ & $33.22 \pm 0.43$ \\
\hline $2.96 \pm 0.62$ & $0.7 \pm 0.48$ & $0.23 \pm 0.05$ & $3.27 \pm 0.65$ \\
\hline $15.07-98.15$ & $34.73-86.65$ & $31.15-97.25$ & 48.59-99.05 \\
\hline $1.54-78.35$ & $10.85-43.62$ & $2.29-58.52$ & $0.79-39.48$ \\
\hline $0.31-6.58$ & $2.3-21.65$ & $0.46-13.77$ & $0.16-11.93$ \\
\hline $0.76 \pm 0.29$ & $0.71 \pm 0.30$ & $2.20 \pm 0.80$ & $0.74 \pm 0.49$ \\
\hline $1395 \pm 654$ & $1091 \pm 416$ & $763 \pm 321$ & $1747 \pm 231$ \\
\hline $2.83 \pm 0.72$ & $2.26 \pm 1.47$ & $1.56 \pm 0.64$ & $2.57 \pm 0.71$ \\
\hline $62 \pm 13$ & $40 \pm 13$ & $35 \pm 10$ & $64 \pm 7$ \\
\hline $42.72 \pm 10.10$ & $30.42 \pm 10.86$ & $25.50 \pm 7.04$ & $41.84 \pm 8.34$ \\
\hline $30.04 \pm 9.09$ & $23.39 \pm 9.52$ & $18.34 \pm 5.36$ & $27.48 \pm 9.04$ \\
\hline 49 & 32 & 13 & 34 \\
\hline 28 & 46 & 56 & 43 \\
\hline 19 & 18 & 25 & 21 \\
\hline 4 & 4 & 5 & 2 \\
\hline $\begin{array}{c}\text { Micronephtys } \\
\text { sphaerocirrata (5.81\%), } \\
\text { Aonidella spp. (5.08\%) }\end{array}$ & $\begin{array}{c}\text { Spiophanes spp. } \\
\text { (10.03\%), Aonidella } \\
\text { spp. (7.73\%), } \\
\text { Amphicteis gunneri } \\
\text { (7.35\%), Aricidea lopezi } \\
(5.29 \%) \text {, Eunice indica } \\
\text { (5.02\%) }\end{array}$ & $\begin{array}{c}\text { Prionospio (Minuspio) } \\
\text { spp. (10.45\%), } \\
\text { Amphicteis gunneri } \\
\text { (9.44\%), Kikegaardia } \\
\text { dorsobranchialis } \\
\text { (8.99\%), Spiophanes } \\
\text { spp. (8.16\%), } \\
\text { Levinsenia oculata } \\
\text { (5.72\%) }\end{array}$ & $\begin{array}{c}\text { Prionospio andamensis } \\
(4.52 \%), \text { Lumbrineries } \\
\text { meteorana (4.45\%) }\end{array}$ \\
\hline
\end{tabular}

Eastern margin of Andaman Is.

$100 \mathrm{~m}(n=5)$

$19.92 \pm 1.27$

$34.51 \pm 0.09$

$0.88 \pm 0.15$

38.25-100

$0-41.99$

$0-19.76$

$0.57 \pm 0.36$

$1353 \pm 346$

$3.64 \pm 1.39$

$53 \pm 12$

$33.23 \pm 5.69$

$19.65 \pm 1.95$

36

43

3

Ampharete

agulhasensis (7.36\%),

Spiophanes spp.

(5.67\%)
$200 \mathrm{~m}(n=4)$

$13.97 \pm 1.01$

$34.92 \pm 0.05$

$0.38 \pm 0.02$

$1.85-98.05$

$1.62-67.96$

$0.32-30.19$

$1.76 \pm 1.44$

$1073 \pm 805$

$2.98 \pm 1.82$

$33 \pm 11$

$20.28 \pm 4.11$

$14.10 \pm 1.38$

20

42

37

1

Amphaerete

agulhasensis (12.39\%),

Prionospio spp.

(11.33\%), Linopherus

paucibranchiata

(10.77\%), Aricidea

lopezi (7.26\%),

Levinsenia gracilis (6.54\%) 
Gooday et al., 2009). Observations in the SE Arabian Sea shelf edge $(200 \mathrm{~m})$, also depict the higher diversity of polychaetes in sandy sediments under hydrodynamically active conditions (Abdul Jaleel et al., 2014), as observed in the present study. Within the Andaman region, the distinctions in polychaete communities between the western and eastern margins were due to the variations in the abundance of sedentarian species like Amphicteis gunneri, Levinsenia gracilis, Prionospio andamanensis etc. In the Nicobar region, the DO levels were relatively higher $\left(>0.5 \mathrm{ml} . \mathrm{l}^{-1}\right)$ and the substratum was sandy; species like Syllis spp., Glycera spp., Eunice indica, and Prionospio spp. dominated in these sites. The oligotrophic conditions around the ANI (Ansari and Abidi, 1989) resulted in low OM flux and retention in the sediments $(0.05-3.90 \%)$, in contrast to the continuous OM deposition in other OMZ-impacted margins, which are usually associated with high productivity (Abdul Jaleel et al., 2014; Raman et al., 2015; Khan et al., 2017). This may be a factor resulting in lack of dominance in the study area, where the occurrence of diversified forms was better suited to utilize the available OM. The proximity to high-diversity mesophotic reef areas may also be a reason for the higher diversity at $200 \mathrm{~m}$ depth in the ANI compared to other OMZ-impacted margins of the world.

In general, the fauna of the intermediate depths $(100 \mathrm{~m})$ showed transitional characteristics (in terms of density and diversity), influenced by the prevailing environmental conditions. The influence of sediment texture and DO on polychaete assemblages was clearly depicted at this depth. The characteristic species in the silty and oxygen-poor conditions $\left(>12^{\circ} \mathrm{N}\right.$ of western margin of Andaman Islands) were Aonidella dayi, Spiophanes spp., Prionospio (Minuspio) spp., resembling the assemblages of deeper areas $(200 \mathrm{~m})$. The variations in DO and sediment texture between the western and eastern margin of Andaman Islands was reflected in the species assemblages, with relatively low abundance of errant polychaetes in western margin. Isobathic sites in the Nicobar region were characterized by relatively high $\mathrm{DO}$, and coralline sandy sediments. This region harbored high abundance of predatory errant polychaetes like Syllis spp., Glycera lapidum and G. benguellana, showing similarity with the mesophotic reef areas $(50 \mathrm{~m})$. Localized pockets of finer sediments were also noted in the shallow depths (50 $\mathrm{m}$ ) along the Andaman Islands, and in these sites, the fauna was distinct, being more similar to the deeper areas.

This study clearly distinguishes the ANI margin into the Andaman region and the Nicobar region, based on community structure of polychaetes. These distinctions were affected by the oxygen availability in bottom water and nature of sediments. Changes in these factors potentially have far-reaching consequences on benthic communities in the ANI margin. In the present study, the influence of oxygen minimum conditions is observed along the western (from $\sim 100 \mathrm{~m}$ depth) and eastern (200 m depth) margins of the Andaman Islands. Predicted intensification and expansion of these conditions (Stramma et al., 2010) are likely to alter benthic communities by decreasing diversity, and promoting the proliferation of opportunistic taxa (Levin, 2003). Ocean warming and acidification due to climate change can have severe impacts on the coral reefs (e.g., coral
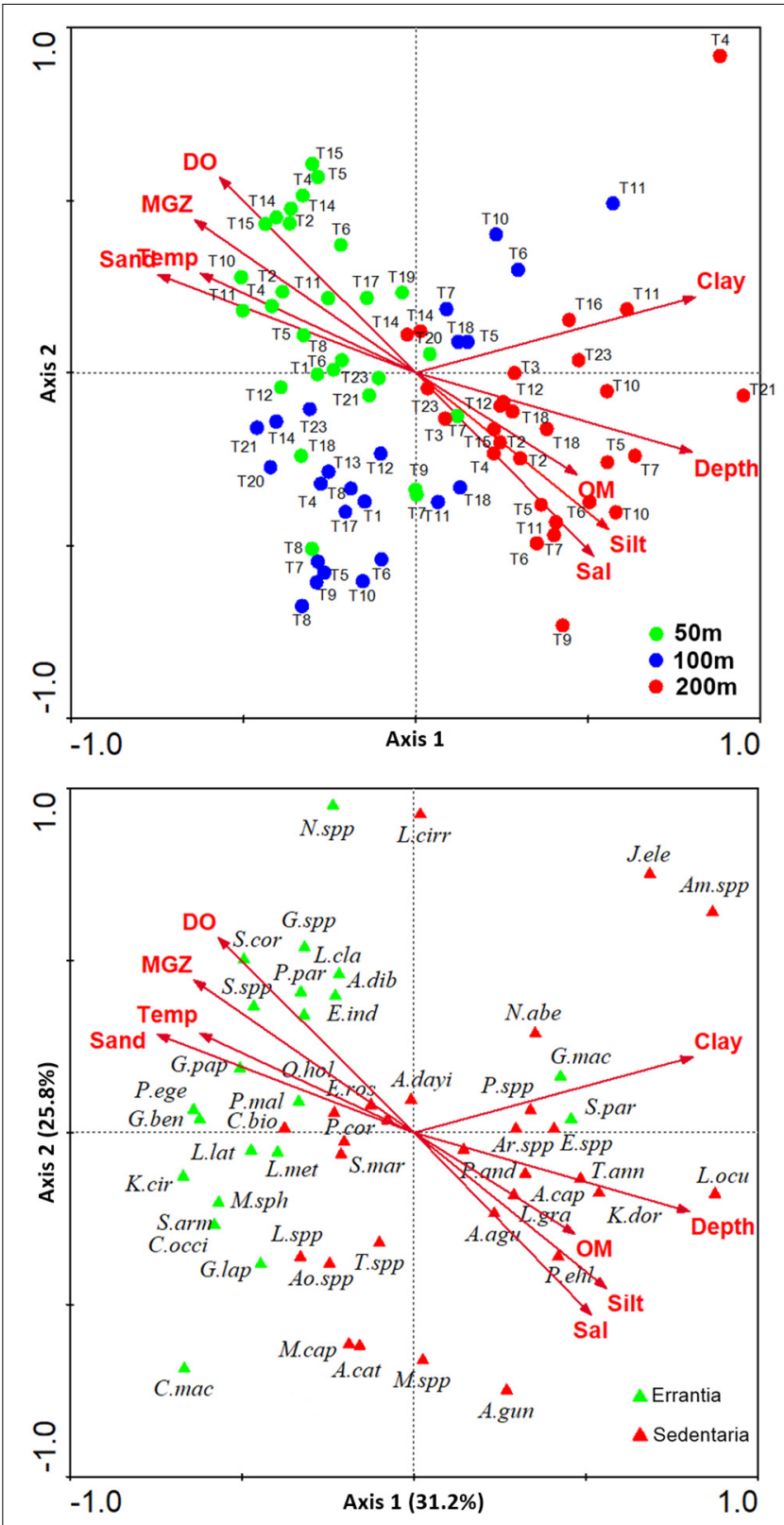

FIGURE 10 | Canonical Correspondence Analysis (CCA) bi-plots showing ordination of (A) sampling sites at $50 \mathrm{~m}$ (green), $100 \mathrm{~m}$ (blue), and $200 \mathrm{~m}$ (red) depth strata, and (B) selected polychaete species (errant polychaete species represented by green triangle and sedent polychaete species by red triangle) with respect to environmental parameters (arrows: Temp-Temperature, Sal-Salinity, DO-Dissolved oxygen, Sand, Silt, Clay, MGZ-Median grain size, OM-Organic matter). See Supplementary Table S7B for abbreviations of polychaete species names.

reef bleaching), as well as associated benthic communities, as these harbor ecologically sensitive fauna (Roberts et al., 2002; Hughes et al., 2003). Coral bleaching, other anthropogenic factors (e.g., fishing, tourism) and consequent coral erosion, will cause changes in sedimentation regimes and surficial sediment characteristics along the insular margin (Baker et al., 2016), thereby impacting community composition of macrozoobenthos. 

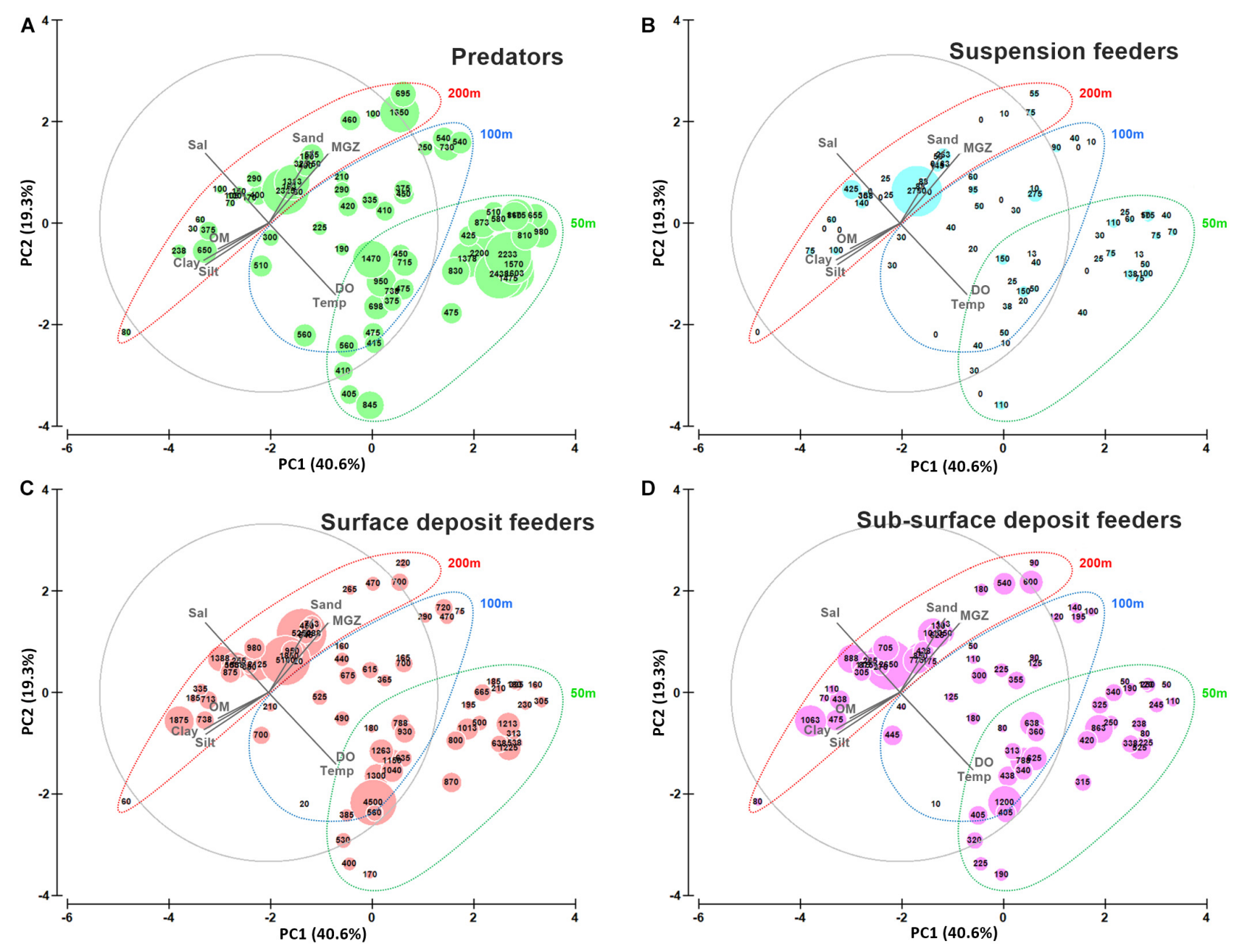

FIGURE 11 | Principal Component Analysis (PCA) bi-plot with superimposed bubbles indicating abundance of polychaete feeding guilds at 50, 100, and 200 $\mathrm{m}$ depth strata. (A) predators (B) suspension feeders, (C) surface deposit feeders and (D) sub-surface deposit feeders with respect to environmental parameters (arrows: Temp-Temperature, Sal-Salinity, DO-Dissolved oxygen, Sand, Silt, Clay, MGZ-Median grain size, OM-Organic matter).

The ANI margin harbors a high proportion of rare species, which have low resilience against alterations in fundamental environmental settings, such as habitat structure and oxygen availability. In the context of climate change-related threats to coral reefs (bleaching, cyclones etc.), to which shallow reefs $(<30 \mathrm{~m}$ depth) are more vulnerable, mesophotic reef areas $(30-$ $150 \mathrm{~m}$ ) are considered to be important refugia by reseeding or replenishing shallow reef populations (Baker et al., 2016; Laverick et al., 2018). Thus, the existence of healthy mesophotic reef areas are important for the health and functioning of shallow reefs, and vice versa, which should be taken into account while developing ecosystem management plans. This can be done by creating new marine protected areas (MPA), or adapting existing MPAs for conservation of mesophotic reef areas, for which mapping of these ecosystems is imperative (de Oliveira Soares et al., 2020).

\section{Methods Discussion}

Inferences on density and distribution patterns of benthic communities are influenced by sampling methods. This includes the type of gear and its bite area, number of samples collected, mesh size of the sieve used to separate organisms and taxonomic resolution of the data used for analysis (James et al., 1995; Schlacher and Wooldridge, 1996; Gage et al., 2002). The present surveys used Smith-McIntyre grabs of two different bite areas and two different mesh sieves for macrozoobenthic studies (Survey 1: $0.2 \mathrm{~m}^{2}$ bite area grab and $500 \mu \mathrm{m}$ mesh sieve; Survey 2: $0.1 \mathrm{~m}^{2}$ bite area grab and $300 \mu \mathrm{m}$ mesh sieve). Macrozoobenthic density was relatively higher in the finer mesh sieve $(300 \mu \mathrm{m}, \mathrm{S} 2)$ compared to coarser mesh sieve $(500 \mu \mathrm{m}$, S1). The retention efficiency of sieve is highly dependent on the habitat being sampled, which determines the body size and shape of resident fauna (Rees, 1984; Thompson et al., 2003). Bathymetric trends in macrozoobenthos standing stock in the present study reflected variations in the size and distribution of dominant faunal groups - the polychaetes and crustaceans. The $300 \mu \mathrm{m}$ mesh with higher retention capacity used in S2 better revealed bathymetric trends in macrozoobenthic standing stock (58\% reduction in density and 35\% reduction in biomass 
from 50 to $200 \mathrm{~m}$ ) and polychaete diversity, despite employing a relatively smaller sampled (bite) area. This was primarily due to the inclusion of small sized interstitial fauna dwelling the interstices of coralline sandy sediments around mesophotic reefs (50 $\mathrm{m}$ depth). Density of other faunal groups, like crustaceans, molluscs and echinoderms were less influenced by the choice of sieve, when compared to polychaetes (Valença and dos Santos, 2013). Macrozoobenthic biomass from the two surveys were comparable since the contribution of larger sized fauna was more significant than small-sized fauna (Schlacher and Wooldridge, 1996; Gage et al., 2002).

A total of 52 polychaete families were represented in the study area, of which 9 were collected only in the finer mesh sieve $(300 \mu \mathrm{m})$. These included small sized and rare interstitial families like Sphaerodoridae, Scalibregmatidae, Saccocirridae, Protodrilidae, Questidae, small sized Syllids, which are important components of biodiversity around oceanic islands (Gage et al., 2002). Moreover, most families were represented by higher numbers of species when the finer mesh was employed, even though the surface sampled in the second survey was nearly half that of the first. The proportion of rare (singleton and doubleton) species was high throughout the ANI, with relatively higher numbers of rare species being collected in the finer mesh sieve. Singletons and doubletons together accounted for more than half of the total number of species represented in the study area. The diversity of polychaetes showed conspicuous decreasing trends with increasing depth which was more clearly depicted in the finer mesh sieve $(300 \mu \mathrm{m})$. While the sample size and sieve size are known to affect estimates of species richness, they do not alter the identity of dominant species in coastal systems (Hammerstrom et al., 2012). This was not the case in the ANI, where dominant species were different in S1 (Aphelochaeta filibranchia, Levinsenia oculata, Kirkegaardia dorsobranchialis, Aonidella cirrobranchiata, Ampharete spp.) and S2 (Ampharete agulhasensis, Prionospio spp., Spiophanes spp., Aonidella spp., Glycera lapidum). This difference in the identity of dominant species between surveys was found to be true at all three depth strata. Thus, in an area with exceptionally high diversity and low species dominance, both sample area and sieve size influence inferences on community composition. The present study reaffirms the fact that in sediments below oligotrophic waters, finer meshes are required to retain macrozoobenthos, as their size will be much smaller compared to productive waters (Hessler and Jumars, 1974).

In order to explain the diversity of a region, emphasis should be placed not only on the number of species and their relative abundance, but also on the degree of diversification at each taxonomic level (e.g., family, genera, species) (Warwick and Clarke, 1995). In the case of macrozoobenthos, conventional diversity indices like species richness, diversity, evenness, dominance, etc. are influenced by sample size and the mesh size of the sieve used to separate them. The taxonomic distinctness index $\left(\Delta^{+}\right)$, is less influenced by these, while at the same time being sensitive to community perturbations (Warwick and Clarke, 1995). In the present study, this index $\left(\Delta^{+}\right)$was employed to overcome the bias arising from use of different methodologies (sample size and mesh size). The taxonomic distinctness index
$\left(\Delta^{+}\right)$was found to be exceptionally high in the archipelago with higher values in the mesophotic reef areas. The relative decrease in $\Delta^{+}$toward deeper areas might be due to the replacement of diversified assemblages by fewer or more closely related species (Somerfield et al., 1997), in response to changes in environmental settings. In an area like ANI, which is prone to pronounced, episodic natural disturbances (e.g., earthquakes and tsunamis), taxonomic distinctness measures can be used to effectively examine their impacts on species diversity, even with the use of multiple sampling methodologies.

\section{CONCLUSION}

The insular margin of the Andaman and Nicobar Islands, which represent a tropical, oceanic, oligotrophic system, has remained poorly studied in terms of quantitative and qualitative composition of macrozoobenthos. The present study, based on comprehensive, stratified sampling in the region $(50-200 \mathrm{~m})$, revealed the highest number of polychaete species ever recorded in the northern Indian Ocean, with several new taxonomic discoveries. This indicates that the waters around Andaman and Nicobar Islands are an important biodiversity hotspot. A finer mesh sieve $(300 \mu \mathrm{m})$ is found to be more suitable for assessing the standing stock, diversity and ecology of macrozoobenthos around oligotrophic oceanic islands, compared to coarser meshes $(500 \mu \mathrm{m})$. Strong regional variations in polychaete assemblages were noted in the study area, which are attributed to the variations in sediment nature as well as hydrodynamics. Owing to the steep depth gradients over short distances across the margin, significant bathymetric variations occurred in composition of macrozoobenthos as well as polychaete community structure. In general, heterogeneous sandy sediments in the mesophotic areas supported taxonomic and functionally diverse polychaete assemblages, including small-sized interstitial forms. The study provided a unique opportunity to examine the community shift when well-oxygenated mesophotic reef areas as well as OMZ conditions occur in close proximity. Oxygen minimum conditions prevailed around the Andaman Islands (200 m), but the polychaete diversity in these sites was higher relative to other OMZ-impacted margins around the world. The Andaman and Nicobar island arc is situated on a tectonically active region, and are susceptible to earthquakes and tsunamis. The region is also vulnerable to climate change-related ocean warming, acidification, cyclonic storms etc., which pose a serious threat to coral reefs and associated habitats. In this context, the present study provides the first detailed information on the distribution of macrozoobenthos around the archipelago, which can be used to study the aftermaths of such disturbances and for developing ecosystem management strategies.

\section{DATA AVAILABILITY STATEMENT}

The datasets generated for this study are available on request to the corresponding author. 


\section{AUTHOR CONTRIBUTIONS}

AG: sample collection, species identification, analysis of data, interpretation, and manuscript preparation. KA: sample collection, statistical analysis of data, interpretation, and manuscript preparation. UP: sample collection, sediment texture analysis and organic matter estimation, estimation of dissolved oxygen, interpretation, and manuscript preparation. VS and AS: conceptualization of study and manuscript correction. NS, AV, GG, and MS: coordination of research program and manuscript correction. All authors contributed to the article and approved the submitted version.

\section{FUNDING}

The research was made under the Marine Living Resources Programme (MLRP), hosted by the Ministry of Earth Sciences (MoES), Government of India.

\section{REFERENCES}

Abdul Jaleel, K. U., Anilkumar, P. R., Khan, K. N., Correya, N. S., Jacob, J., Philip, R., et al. (2014). Polychaete community structure in the South Eastern Arabian Sea continental margin (200-1000 m). Deep Sea Res. I 93, 60-71. doi: 10.1016/j.dsr.2014.07.006

Allen, G. R. (2008). Conservation hotspots of biodiversity and endemism for Indo-Pacific coral reef fishes. Aquat. Conserv. 18, 541-556. doi: 10.1002/aqc.880

Alongi, D. M., Tirendi, F., and Goldrick, A. (1996). Organic matter oxidation and sediment chemistry in mixed terrigenous-carbonate sands of Ningaloo Reef, Western Australia. Mar. Chem. 54, 203-219. doi: 10.1016/0304-4203(96) 00037-0

Anderson, M., Gorley, R. N., and Clarke, R. K. (2008). Permanova+ for Primer: Guide to Software and Statistical Methods. Auckland: Primer-E Limited.

Anderson, T. J., McArthur, M. A., Syms, C., Nichol, S., and Brooke, B. (2013). Infaunal biodiversity and ecological function on a remote oceanic island: the role of biogeography and bio-physical surrogates. Estuar. Coast. Shelf Sci. 117, 227-237. doi: 10.1016/j.ecss.2012.11.013

Ansari, Z. A., and Abidi, S. A. H. (1989). "Andaman Sea-its physical, chemical and biological characteristics," in Management of Aquatic Ecosystems, eds V. P. Agrawal, and S. A. H. Abidi, (Delhi: Narendra Publishing House), 21-32.

Ansari, Z. A., Furtado, R., Badesab, S., Mehta, P., and Thwin, S. (2012). Benthic macroinvertebrate community structure and distribution in the Ayeyarwady continental shelf, Andaman Sea. Indian J. Geo Mar. Sci. 41, 272-278.

Ansari, Z. A., Ramani, P., Rivonker, C. U., and Parulekar, A. H. (1990). Macro and meiofaunal abundance in six sandy beaches of Lakshadweep islands. Indian J. Mar. Sci. 19, 159-164.

Ansari, Z. A., Rivonker, C. U., Ramani, P., and Parulekar, A. H. (1991). Seagrass habitat complexity and macroinvertebrate abundance in Lakshadweep coral reef lagoons, Arabian Sea. Coral Reefs 10, 127-131. doi: 10.1007/bf00572170

Bahuguna, A., and Nayak, S. (1998). Coral Reefs of the Indian Coast, Scientific Note (SAC/RSA/RSAG/DOD-COS/SN/16/97). (Ahmedabad: Space Application Centre), 56.

Baker, E. K., Puglise, K. A., and Harris, P. T. (2016). Mesophotic Coral Ecosystems A Lifeboat for Coral Reefs? Nairobi: The United Nations Environment Programme, 98.

Bigot, L., Quod, J. P., and Conand, C. (2006). Bathymetric distribution of soft bottom tropical macrobenthos from the exposed east coast of Reunion Island (Southwest Indian Ocean). West. Indian Ocean J. Mar. Sci. 5, 1-16.

\section{ACKNOWLEDGMENTS}

The support of Scientists and research staff at CMLRE and onboard FORV Sagar Sampada is acknowledged with gratitude. The authors also acknowledge timely help from Mrs. Shruthi Venugopal, Mrs. Chippy Khader, Mr. Johnny Konjarla, Dr. Sumisha Velloth, and Dr. Sudhanshu Dixit. Sediment texture analysis was carried out at the National Centre for Earth Science Studies (NCESS), Ministry of Earth Sciences. This is CMLRE Contribution No. 118.

\section{SUPPLEMENTARY MATERIAL}

The Supplementary Material for this article can be found online at: https://www.frontiersin.org/articles/10.3389/fmars. 2020.00710/full\#supplementary-material

FIGURE S1 | Polychaete species from the Andaman and Nicobar Island margin. (A) Palmyreuphrosyne sp., (B) Armandia sampadae, (C) Paraprionospio pinnata, (D) Sphaerosyllis sp., (E) Pettibonella shopmens, (F) Rhamphobrachium sp.

Böggemann, M., and Eibye-Jacobsen, D. (2002). The Glyceridae and Goniadidae (Annelida: Polychaeta) of the BIOSHELF Project, Andaman Sea, Thailand. Spec. Publ. Phuket Mar. Biol. Cent. 24, 149-196.

Brown, B. E. (2005). The fate of coral reefs in the Andaman Sea, eastern Indian Ocean following the Sumatran earthquake and tsunami, 26 December 2004. Geogr. J. 171, 372-374. doi: 10.1111/j.1475-4959.2005.00175_2.x

Bussarawit, S., Secher Tendal, O., Nielsen, C., and Rasmussen, A. R. (2008). Sea Continental Shelf and Slope (1996-2000). Spec. Publ. Phuket Mar. Biol. Cent. 31, 75-81.

Carson, H. S., and Hentschel, B. T. (2006). Estimating the dispersal potential of polychaete species in the Southern California Bight: implications for designing marine reserves. Mar. Ecol. Prog. Ser. 316, 105-113. doi: 10.3354/meps316105

Chandran, S. T., Raj, S. B., Ravindran, S., and Narayana, S. V. (2018). Upper layer circulation, hydrography, and biological response of the Andaman waters during winter monsoon based on in situ and satellite observations. Ocean Dyn. 68, 801-815. doi: 10.1007/s10236-018-1160-x

Chatananthawej, B., and Bussarawit, S. (1987). Quantitative survey of the macrobenthic fauna along the west coast of Thailand in the Andaman Sea. Phuket Mar. Biol. Cent. Res. Bull. 47, 1-23.

Cheung, S. G., Lam, N. W. Y., Wu, R. S. S., and Shin, P. K. S. (2008). Spatiotemporal changes of marine macrobenthic community in sub-tropical waters upon recovery from eutrophication. II. Life-history traits and feeding guilds of polychaete community. Mar. Pollut. Bull. 56, 297-307. doi: 10.1016/j. marpolbul.2007.10.019

Clarke, K. R., and Warwick, R. M. (2001). A further biodiversity index applicable to species lists: variation in taxonomic distinctness. Mar. Ecol. Prog. Ser. 216, 265-278. doi: 10.3354/meps216265

Curray, J. R. (2005). Tectonics and history of the Andaman Sea region. J. Asian Earth Sci. 25, 187-232. doi: 10.1016/j.jseaes.2004.09.001

Dahanayaka, D. D. G. L., Jayamanne, S. C., and Jinadasa, S. U. P. (2007). Hydrobiological aspects of Palk Bay and Palk Strait area. J. Nat. Aquat. Resour. Res. Dev. Agency 38, 33-44.

Damodaran, R. (2010). Investigations on the Benthic Productivity in the EEZ of India (1998-2002) Final Report. Cochin: Cochin University of Science and Technology, 214.

Dauer, D. M., Maybury, C. A., and Ewing, R. M. (1981). Feeding behavior and general ecology of several spionid polychaetes from the Chesapeake Bay. J. Exp. Mar. Biol. Ecol. 54, 21-38. doi: 10.1016/0022-0981(81)90 $100-3$ 
de Oliveira Soares, M., de Araújo, J. T., Ferreira, S. M. C., Santos, B. A., Boavida, J. R. H., Costantini, F., et al. (2020). Why do mesophotic coral ecosystems have to be protected? Sci. Total Environ. 138456, 1-10.

de Paiva, P. C. (1993). Trophic structure of a shelf polychaete taxocoenosis in southern Brazil. Cah. Biol. Mar. 35, 39-55.

Demopoulos, A. W., Bourque, J. R., and Frometa, J. (2014). Biodiversity and community composition of sediment macrofauna associated with deep-sea Lophelia pertusa habitats in the Gulf of Mexico. Deep Sea Res. I 93, 91-103. doi: 10.1016/j.dsr.2014.07.014

Diaz, R. J., and Rosenberg, R. (1995). "Marine benthic hypoxia: a review of its ecological effects and the behavioural responses of benthic macrofauna," in Oceanography and Marine Biology: an Annual Review, Vol. 33, eds A. D. Ansell, R. N. Gibson, and M. Barnes, (London: Aberdeen University Press), 245-303.

Dolbeth, M., Teixeira, H., Marques, J. C., and Pardal, M. Â. (2009). Feeding guild composition of a macrobenthic subtidal community along a depth gradient. Sci. Mar. 73, 225-237. doi: 10.3989/scimar.2009.73n2225

Eibye-Jacobsen, D. (2002). Scalibregmatidae and Opheliidae (Annelida: Polychaeta) collected in the Andaman Sea, Thailand, during the BIOSHELF project. Spec. Publ. Phuket Mar. Biol. Cent. 24, 57-74.

Ellingsen, K. E., Hewitt, J. E., and Thrush, S. F. (2007). Rare species, habitat diversity and functional redundancy in marine benthos. J. Sea Res. 58, 291-301. doi: 10.1016/j.seares.2007.10.001

El-Wakeel, S. K., and Riley, J. P. (1957). The determination of organic carbon in marine muds. $\iota$ ICES J. Mar. Sci. 22, 180-183. doi: 10.1093/icesjms/22.2.180

Fauchald, K. (1977). The Polychaete worms: definitions and key to the orders, families and genera. Nat. Hist. Museum Los Angeles County Sci. Ser. 28, 1-188.

Fauchald, K., and Jumars, P. A. (1979). The diet of worms: a study of polychaete feeding guilds. Oceanogr. Mar. Biol. Ann. Rev. 17, 193-284.

Fauvel, P. (1953). Annelida Polychaeta. The Fauna of India Including Pakistan, Ceylon, Burma and Malaya. Allahabad: The Indian Press.

Gage, J. D., Hughes, D. J., and Vecino, J. L. G. (2002). Sieve size influence in estimating biomass, abundance and diversity in samples of deep-sea macrobenthos. Mar. Ecol. Prog. Ser. 225, 97-107. doi: 10.3354/meps 225097

Ganesh, T., and Raman, A. V. (2007). Macrobenthic community structure of the northeast Indian shelf. Bay of Bengal. Mar. Ecol. Prog. Ser. 341, 59-73. doi: 10.3354/meps341059

Garg, J. N., Murty, C. B., and Jayaraman, R. (1968). Vertical distribution of oxygen in the Bay of Bengal and Andaman Sea during February-March 1963. Bull. Natl. Inst. Sci. India 38, 40-48.

Gaston, K. J. (1994). Measuring geographic range sizes. Ecography 17, 198-205. doi: 10.1111/j.1600-0587.1994.tb00094.x

Giangrande, A., Licciano, M., and Musco, L. (2005). Polychaetes as environmental indicators revisited. Mar. Pollut. Bull. 50, 1153-1162. doi: 10.1016/j.marpolbul. 2005.08.003

Glynn, P. W. (1993). Coral reef bleaching: ecological perspectives. Coral Reefs 12, 1-17. doi: 10.1007/bf00303779

Gooday, A. J., Levin, L. A., da Silva, A. A., Bett, B. J., Cowie, G. L., Dissard, D., et al. (2009). Faunal responses to oxygen gradients on the Pakistan margin: a comparison of foraminiferans, macrofauna and megafauna. Deep Sea Res. II 56, 488-502. doi: 10.1016/j.dsr2.2008.10.003

Gopal, A., Abdul Jaleel, K. U., Saramma, A. V., and Sanjeevan, V. N. (2014). A new species of polychaete, Pettibonella shompens sp. nov. (Orbiniidae), from the Nicobar Islands, North Indian Ocean. Mar. Biol. Res. 10, 1033-1037. doi: 10.1080/17451000.2013.879988

Gopal, A., Abdul Jaleel, K. U., Parameswaran, U. V., and Vijayan, A. K. (2016). Armandia sampadae, a new species of polychaete (Opheliidae) from Andaman Sea, Northern Indian Ocean. J. Mar. Biol. Assoc. U.K. 96, 1625-1632. doi: $10.1017 /$ s002531541500199x

Gopal, A., Parameswaran, U. V., Abdul Jaleel, K. U., and Saravanane, N. (2020). Prionospio atrovitta (Annelida: Spionidae), a new species from Andaman and Nicobar archipelago, northern Indian Ocean. Mar. Biol. Res. 16, 134-140. doi: 10.1080/17451000.2019.1708950

Griffiths, J. R., Kadin, M., Nascimento, F. J., Tamelander, T., Törnroos, A., Bonaglia, S., et al. (2017). The importance of benthic-pelagic coupling for marine ecosystem functioning in a changing world. Glob. Chang. Biol. 23, 2179-2196. doi: $10.1111 /$ gcb. 13642
Gupta, R. S., Moraes, C., George, M. D., Kureishy, T. W., Noronha, R. J., and Fondekar, S. P. (1981). Chemistry and hydrography of the Andaman Sea. Indian J. Mar. Sci. 10, 228-233.

Hammerstrom, K. K., Ranasinghe, J. A., Weisberg, S. B., Oliver, J. S., Fairey, W. R., Slattery, P. N., et al. (2012). Effect of sample area and sieve size on benthic macrofaunal community condition assessments in California enclosed bays and estuaries. Integr. Environ. Assess. Manage. 8, 649-658. doi: 10.1002/ieam.78

Hashimi, N. H., Kidwai, R. M., and Nair, R. R. (1981). Comparative study of the topography and sediments of the western and eastern continental shelves around Cape Comorin. Indian J. Mar. Sci. 10, 45-50.

Helly, J. J., and Levin, L. A. (2004). Global distribution of naturally occurring marine hypoxia on continental margins. Deep Sea Res. I 51, 1159-1168. doi: 10.1016/j.dsr.2004.03.009

Hessler, R. R., and Jumars, P. A. (1974). Abyssal community analysis from replicate box cores in the central North Pacific. Deep Sea Res. Oceanogr. Abstr. 21, 185-209. doi: 10.1016/0011-7471(74)90058-8

Hoegh-Guldberg, O. (1999). Climate change, coral bleaching and the future of the world's coral reefs. Mar. Freshw. Res. 50, 839-866.

Hughes, T. P., Baird, A. H., Bellwood, D. R., Card, M., Connolly, S. R., Folke, C., et al. (2003). Climate change, human impacts, and the resilience of coral reefs. Science 301, 929-933. doi: 10.1126/science. 1085046

Hutchings, P. (1998). Biodiversity and functioning of polychaetes in benthic sediments. Biodivers. Conserv. 7, 1133-1145. doi: 10.1023/a:1008871430178

Ibrahim, S., Hussin, W. M. R. W., Kassim, Z., Joni, Z. M., Zakaria, M. Z., and Hajisamae, S. (2006). Seasonal abundance of benthic communities in coral areas of Karah Island, Terengganu, Malaysia. Turk. J. Fish. Aquat. Sci. 6, 129-136.

Ingole, B. S., Ansari, Z. A., and Parulekar, A. H. (1992). Benthic fauna around Mauritius island, southwest Indian Ocean. Indian J. Mar. Sci. 21, 268-268.

Ingole, B. S., Sautya, S., Sivadas, S., Singh, R., and Nanajkar, M. (2010). Macrofaunal community structure in the western Indian continental margin including the oxygen minimum zone. Mar. Ecol. 31, 148-166. doi: 10.1111/j.1439-0485.2009. 00356.x

James, R. J., Smith, M. L., and Fairweather, P. G. (1995). Sieve mesh-size and taxonomic resolution needed to describe natural spatial variation of marine macrofauna. Mar. Ecol. Prog. Ser. 118, 187-198. doi: 10.3354/meps118187

Janßen, A., Wizemann, A., Klicpera, A., Satari, D. Y., Westphal, H., and Mann, T. (2017). Sediment composition and facies of coral reef islands in the Spermonde Archipelago, Indonesia. Front. Mar. Sci. 4:144.

Joydas, T. V., and Damodaran, R. (2009). Infaunal macrobenthos along the shelf waters of the west coast of India, Arabian Sea. Indian J. Mar. Sci. 38, 191-204.

Joydas, T. V., and Damodaran, R. (2014). Infaunal macrobenthos of the oxygen minimum zone on the Indian western continental shelf. Mar. Ecol. 35, 22-35. doi: $10.1111 /$ maec. 12052

Jumars, P. A., Dorgan, K. M., and Lindsay, S. M. (2015). Diet of worms emended: an update of polychaete feeding guilds. Annu. Rev. Mar. Sci. 7, 497-520. doi: 10.1146/annurev-marine-010814-020007

Karakassis, I., and Eleftheriou, A. (1997). The continental shelf of Crete: structure of macrobenthic communities. Mar. Ecol. Prog. Ser. 160, 185-196. doi: 10.3354/ meps 160185

Keil, R. G., Tsamakis, E., Fuh, C. B., Giddings, J. C., and Hedges, J. I. (1994). Mineralogical and textural controls on the organic composition of coastal marine sediments: hydrodynamic separation using SPLITT-fractionation. Geochim Cosmochim. Acta 58, 879-893. doi: 10.1016/0016-7037(94)90512-6

Khan, A., Manokaran, S., and Lyla, S. (2017). Changes in macrobenthic community structure from estuary to continental slope in the south-east coast of India. J. Mar. Biol. Assoc. U.K. 97, 161-180. doi: 10.1017/s0025315416000229

Kramer, M. J., Bellwood, D. R., and Bellwood, O. (2014). Benthic Crustacea on coral reefs: a quantitative survey. Mar. Ecol. Prog. Ser. 511, 105-116.

Lakra, R. K., Ganesh, T., Sahu, N., Equbal, J., Savurirajan, M., and Satyam, K. (2018). New records of Glyceridae (Annelida: Polychaeta) from South Andaman Coast, Andaman and Nicobar Islands, India. Proc. Int. Acad. Ecol. Environ. Sci. 8:56.

Lamont, P. A., and Gage, J. D. (2000). Morphological responses of macrobenthic polychaetes to low oxygen on the Oman continental slope, NW Arabian Sea. Deep Sea Res. II 47, 9-24. doi: 10.1016/s0967-0645(99)00 102-2 
Largier, J. L. (2003). Considerations in estimating larval dispersal distances from oceanographic data. Ecol. Appl. 13, 71-89. doi: 10.1890/1051-0761(2003) 013[0071:cieldd]2.0.co;2

Laverick, J. H., Piango, S., Andradi-Brown, D. A., Exton, D. A., Bongaerts, P., Bridge, T. C., et al. (2018). To what extent do mesophotic coral ecosystems and shallow reefs share species of conservation interest? A systematic review. Environ. Evid. 7:15.

Levin, L. A. (2003). "Oxygen minimum zone benthos: adaptation and community response to hypoxia," in Oceanography and Marine Biology: an Annual Review, Vol. 41, eds R. N. Gibson, and R. J. A. Atkinson, (London: Aberdeen University Press), 1-45.

Levin, L. A., and Gage, J. D. (1998). Relationships between oxygen, organic matter and the diversity of bathyal macrofauna. Deep Sea Res. II 45, 129-163. doi: 10.1016/s0967-0645(97)00085-4

Levin, L. A., Gage, J. D., Martin, C., and Lamont, P. A. (2000). Macrobenthic community structure within and beneath the oxygen minimum zone, NW Arabian Sea. Deep Sea Res. II 47, 189-226. doi: 10.1016/s0967-0645(99)00103-4

Li, M. Z., and Amos, C. L. (1999). Sheet flow and large wave ripples under combined waves and currents: field observations, model predictions and effects on boundary layer dynamics. Cont. Shelf Res. 19, 637-663. doi: 10.1016/s02784343(98)00094-6

Mackie, A. S., Oliver, P. G., Darbyshire, T., and Mortimer, K. (2005). Shallow marine benthic invertebrates of the Seychelles Plateau: high diversity in a tropical oligotrophic environment. Philos. Trans. R. Soc. A 363, 203-228. doi: 10.1098/rsta.2004.1488

Madhu, N. V., Jyothibabu, R., Ramu, K., Sunil, V., Gopalakrishnan, T. C., and Nair, K. K. C. (2003). Vertical distribution of mesozooplankton biomass in relation to oxygen minimum layer in the Andaman Sea. Indian J. Fish. 50, 533-538.

Mahendra, R. S., Bisoyi, H., Mohanty, P. C., Velloth, S., Srinivasa Kumar, T., and Nayak, S. (2010). Applications of the multi-spectral satellite data from IRS-P6 LISS-III and IRS-P4 OCM to decipher submerged coral beds around Andaman Islands. Int. J. Earth Sci. 3, 626-631.

Manokaran, S., Khan, S. A., and Lyla, P. S. (2015). Macrobenthic composition of the southeast continental shelf of India. Mar. Ecol. 36, 1-15. doi: 10.1111/maec. 12107

Marchese, C. (2015). Biodiversity hotspots: a shortcut for a more complicated concept. Glob. Ecol. Conserv. 3, 297-309. doi: 10.1016/j.gecco.2014.12.008

Martins, R., Magalhães, L., Peter, A., San Martín, G., Rodrigues, A. M., and Quintino, V. (2013). Diversity, distribution and ecology of the family Syllidae (Annelida) in the Portuguese coast (Western Iberian Peninsula). Helgol. Mar. Res. 67, 775-788. doi: 10.1007/s10152-013-0362-3

McArthur, M. A., Brooke, B. P., Przeslawski, R., Ryan, D. A., Lucieer, V. L., Nichol, S., et al. (2010). On the use of abiotic surrogates to describe marine benthic biodiversity. Estuar. Coast. Mar. Sci. 88, 21-32. doi: 10.1016/j.ecss.2010.03.003

McCarthy, S. A., Laws, E. A., Estabrooks, W. A., Bailey-Brock, J. H., and Kay, E. A. (2000). Intra-annual variability in Hawaiian shallow-water, soft-bottom macrobenthic communities adjacent to a eutrophic estuary. Estuar. Coast. Shelf Sci. 50, 245-258. doi: 10.1006/ecss. 1999.0559

Mohanty, P. C., Venkateshwaran, P., Mahendra, R. S., Kumar, H. S., Kumar, T. S., Vinithkumar, N.V., et al. (2017). Coral bleaching along Andaman coast due to thermal stress during summer months of 2016: a geospatial assessment. Am. J. Environ. Prot. 6, 1-6.

Mondal, T., Raghunathan, C., and Venkataraman, K. (2014). Coral bleaching in Andaman Sea-an indicator for climate change in Andaman and Nicobar Islands. Indian J. Mar. Sci. 43, 1945-1948.

Myers, N., Mittermeier, R. A., Mittermeier, C. G., Da Fonseca, G. A., and Kent, J. (2000). Biodiversity hotspots for conservation priorities. Nature 403, 853-858. doi: 10.1038/35002501

Nair, V. R., and Gireesh, R. (2010). Biodiversity of chaetognaths of the Andaman Sea, Indian Ocean. Deep Sea Res. II 57, 2135-2147. doi: 10.1016/j.dsr2.2010. 09.016

Narayanaswamy, B. E., Rea, T., Serpetti, N., and Lamont, P. A. (2017). What lies within; Annelid polychaetes found in micro-habitats of coral/carbonate material from SW Indian Ocean seamounts. Deep Sea Res. II 137, 157-165.

Nassaj, S. M. S., Nabavi, S. M. B., Yavari, V., Savari, A., and Maryamabadi, A. (2010). Species Diversity of Macrobenthic Communities in Salakh Region, Qeshm Island, Iran. World 2, 539-544.
Navarro-Barranco, C., and Guerra-García, J. M. (2016). Spatial distribution of crustaceans associated with shallow soft-bottom habitats in a coral reef lagoon. Mar. Ecol. 37, 77-87. doi: 10.1111/maec.12251

Olsgard, F., Brattegard, T., and Holthe, T. (2003). Polychaetes as surrogates for marine biodiversity: lower taxonomic resolution and indicator groups. Biodivers. Conserv. 12, 1033-1049.

Otegui, M. B., Brauko, K. M., and Pagliosa, P. R. (2016). Matching ecological functioning with polychaete morphology: Consistency patterns along sedimentary habitats. J. Sea Res. 114, 13-21. doi: 10.1016/j.seares.2016.05.001

Pagliosa, P. R. (2005). Another diet of worms: the applicability of polychaete feeding guilds as a useful conceptual framework and biological variable. Mar. Ecol 26, 246-254. doi: 10.1111/j.1439-0485.2005.00065.x

Parameswaran, U. V., Abdul Jaleel, K. U., Sanjeevan, V. N., Gopal, A., Vijayan, A. K., Gupta, G. V. M., et al. (2018). Diversity and distribution of echinoderms in the South Eastern Arabian Sea shelf under the influence of seasonal hypoxia. Prog. Oceanogr. 165, 189-204. doi: 10.1016/j.pocean.2018.06.005

Parker, T., and Tunnicliffe, V. (1994). Dispersal strategies of the biota on an oceanic seamount: implications for ecology and biogeography. Biol. Bull. 187, 336-345. doi: $10.2307 / 1542290$

Parulekar, A. H., and Ansari, Z. A. (1981). Benthic macrofauna of the Andaman Sea. Indian J. Mar. Sci. 10, 280-284.

Pilditch, C. A., Valanko, S., Norkko, J., and Norkko, A. (2015). Post-settlement dispersal: the neglected link in maintenance of soft-sediment biodiversity. Biol. Lett. 11, 1-6.

Preston, N. P., and Doherty, P. J. (1994). Cross-shelf patterns in the community structure of coral-dwelling crustacea in the central region of the Great Barrier Reef. II. Cryptofauna. Mar. Ecol. Prog. Ser. 104, 27-38. doi: 10.3354/ meps 104027

Przeslawski, R., McArthur, M. A., and Anderson, T. J. (2013). Infaunal biodiversity patterns from Carnarvon shelf (Ningaloo reef), Western Australia. Mar. Freshw. Res. 64, 573-583.

Qian, P., and Dahms, H. U. (2005). "Larval ecology of Annelida," in Reproductive Biology and Phylogeny of Annelida, Vol. 4, eds F. Rouse, and G. W. Pleijel, (St. Lucia: CRC Press), 189-244. doi: 10.1201/9781482280159-6

Rajasekaran, R. (2015). Some polychaetes (Annelida) are new distributional records to Andaman and Nicobar Islands. IJRAR 2, 707-714.

Rajasekaran, R., and Fernando, O. J. (2012). "Polychaetes of Andaman and Nicobar Islands," in Ecology of Faunal Communities on the Andaman and Nicobar Islands, eds K. Venkataraman, C. Raghunathan, and C. Sivaperuman, (Berlin: Springer-Verlag), 1-23.

Rama Raju, D. V., Gouveia, A. D., and Murty, C. S. (1981). Some physical characteristics of Andaman Sea waters during winter. Indian J. Mar. Sci. 10, 211-218.

Raman, A. V., Damodaran, R., Levin, L. A., Ganesh, T., Rao, Y. K., Nanduri, S., et al. (2015). Macrobenthos relative to the oxygen minimum zone on the East Indian margin, Bay of Bengal. Mar. Ecol. 36, 679-700. doi: 10.1111/maec.12176

Ramaswamy, V., Rao, P. S., Rao, K. H., Thwin, S., Rao, N. S., and Raiker, V. (2004). Tidal influence on suspended sediment distribution and dispersal in the northern Andaman Sea and Gulf of Martaban. Mar. Geol. 208, 33-42. doi: 10.1016/j.margeo.2004.04.019

Rao, P. S., Ramaswamy, V., and Thwin, S. (2005). Sediment texture, distribution and transport on the Ayeyarwady continental shelf, Andaman Sea. Mar. Geol. 216, 239-247. doi: 10.1016/j.margeo.2005.02.016

Rao, V. P., and Kessarkar, P. M. (2001). "Geomorphology and geology of the Bay of Bengal and the Andaman Sea," in The Indian Ocean: A Perspective, Vol. 2, eds R. Sen Gupta, and E. Desa, (New Delhi: Oxford and IBH), 817-868.

Rees, H. L. (1984). A note on mesh selection and sampling efficiency in benthic studies. Mar. Pollut. Bull. 15, 225-229. doi: 10.1016/0025-326x(84)90293-5

Rex, M. A., Etter, R. J., Morris, J. S., Crouse, J., McClain, C. R., Johnson, N. A., et al. (2006). Global bathymetric patterns of standing stock and body size in the deep-sea benthos. Mar. Ecol. Prog. Ser. 317, 1-8. doi: 10.3354/meps317001

Riddle, M. J. (1988). Patterns in the distribution of macrofaunal communities in coral reef sediments on the central Great Barrier Reef. Mar. Ecol. Prog. Ser. 47, 281-292. doi: 10.3354/meps047281

Rivonker, C. U., and Sangodkar, U. M. X. (1997). Macrofaunal density along the intertidal region of three atolls of Lakshadweep, Arabian Sea. Indian J. Fish. 44, 345-352. 
Roberts, C. M., McClean, C. J., Veron, J. E., Hawkins, J. P., Allen, G. R., McAllister, D. E., et al. (2002). Marine biodiversity hotspots and conservation priorities for tropical reefs. Science 295, 1280-1284. doi: 10.1126/science.1067728

Rodolfo, K. S. (1969). Sediments of the Andaman basin, northeastern Indian Ocean. Mar. Geol. 7, 371-402. doi: 10.1016/0025-3227(69)90014-0

Rouse, G., and Pleijel, F. (2001). Polychaetes. Oxford: Oxford University Press.

Sarma, V. V. S. S., Rao, G. D., Viswanadham, R., Sherin, C. K., Salisbury, J., Omand, M. M., et al. (2016). Effects of freshwater stratification on nutrients, dissolved oxygen, and phytoplankton in the Bay of Bengal. Oceanography 29, 222-231. doi: 10.5670/oceanog.2016.54

Sarupria, J. S., and Bhargava, R. M. S. (1993). Seasonal primary production in different sectors of the EEZ of India. Mahasagar 26, 139-147.

Schlacher, T. A., and Wooldridge, T. H. (1996). How sieve mesh size affects sample estimates of estuarine benthic macrofauna. J. Exp. Mar. Biol. Ecol. 201, 159-171. doi: 10.1016/0022-0981(95)00198-0

Shepard, F. P. (1954). Nomenclature based on sand-silt-clay ratios. J. Sediment Res. 24, 151-158.

Sherman, C., Schmidt, W., Appeldoorn, R., Hutchinson, Y., Ruiz, H., Nemeth, M., et al. (2016). Sediment dynamics and their potential influence on insular-slope mesophotic coral ecosystems. Cont. Shelf Res. 129, 1-9. doi: 10.1016/j.csr.2016. 09.012

Shetye, S. R. (1993). The movement and implications of the Ganges-Brahmaputra runoff on entering the Bay of Bengal. J. Geophys. Res. 64, 32-38.

Sibaja-Cordero, J. A., Troncoso, J. S., Cortés, J., Moreira, J., Vargas, J. A., and Benavides-Varela, C. (2016). Biodiversity and density of subtidal benthos of an oceanic tropical island (a comparison within the Pacific Ocean). J. Sea Res. 115, 47-58. doi: 10.1016/j.seares.2016.07.004

Snelgrove, P. V. (1998). The biodiversity of macrofaunal organisms in marine sediments. Biodivers. Conserv. 7, 1123-1132. doi: 10.1023/a:100886731 3340

Snelgrove, P. V. (1999). Getting to the bottom of marine biodiversity: sedimentary habitats: ocean bottoms are the most widespread habitat on earth and support high biodiversity and key ecosystem services. Bioscience 49, 129-138.

Somerfield, P. J., Olsgard, F., and Carr, M. R. (1997). A further examination of two new taxonomic distinctness measures. Mar. Ecol. Prog. Ser. 154, 303-306. doi: $10.3354 /$ meps 154303

Stramma, L., Schmidtko, S., Levin, L. A., and Johnson, G. C. (2010). Ocean oxygen minima expansions and their biological impacts. Deep Sea Res. I 57, 587-595. doi: 10.1016/j.dsr.2010.01.005

Susan, V. D., Kumar, P. S., and Pillai, K. (2014). Biodiversity and seasonal variation of benthic macrofauna in Minicoy Island, Lakshadweep, India. Acta Oceanol. Sin. 33, 58-73. doi: 10.1007/s13131-0140541-3

ter Braak, C. J., and Smilauer, P. (2002). CANOCO Reference Manual and CanoDraw for Windows User's Guide: Software for Canonical Community Ordination (version 4.5). Wageningen: Biometris.

Thadathil, P., Gopalakrishna, V. V., Muraleedharan, P. M., Reddy, G. V., Araligidad, N., and Shenoy, S. (2002). Surface layer temperature inversion in the Bay of Bengal. Deep Sea Res. II 49, 1801-1818. doi: 10.1016/s0967-0637(02) 00044- 4

Thompson, B. W., Riddle, M. J., and Stark, J. S. (2003). Cost-efficient methods for marine pollution monitoring at Casey Station, East Antarctica: the choice of sieve mesh-size and taxonomic resolution. Mar. Pollut. Bull. 46, 232-243. doi: 10.1016/s0025-326x(02)00366-1

Trask, P. D. (1939). “Organic content of recent marine sediments," in Recent Marine Sediments, ed. P. D. Trask, (Tulsa: Society of Economic Paleontologists and Mineralogists), 428-453. doi: 10.2110/pec.55.04.0428

UNEP/IUCN (1988). Coral Reefs of the World. Vol 2, Indian Ocean, Red Sea and Gulf. UNEP Regional Seas Directories and Bibliographies. Gland: IUCN.

Valença, A. P. M. C., and dos Santos, P. J. P. (2013). Macrobenthic community structure in tropical estuaries: the effect of sieve mesh-size and sampling depth on estimated abundance, biomass and composition. J. Mar. Biol. Assoc. U.K. 93, 1441-1456. doi: 10.1017/s0025315413000039

Velloth, S., Mupparthy, R. S., Raghavan, B. R., and Nayak, S. (2014). Coupled correction and classification of hyperspectral imagery for mapping coral reefs of Agatti and Flat Islands, India. Int. J. Remote Sens. 35, 5544-5561. doi: 10.1080/01431161.2014.926410

Veron, J. E. N., Devantier, L. M., Turak, E., Green, A. L., Kininmonth, S., StaffordSmith, M., et al. (2009). Delineating the coral triangle. Galaxea J. Coral Reef Stud. 11, 91-100. doi: 10.3755/galaxea.11.91

Warwick, R. M., and Clarke, K. R. (1995). New 'biodiversity' measures reveal a decrease in taxonomic distinctness with increasing stress. Mar. Ecol. Prog. Ser. 129, 301-305. doi: 10.3354/meps129301

Williams, K. J., Ford, A., Rosauer, D. F., De Silva, N., Mittermeier, R., Bruce, C., et al. (2011). "Forests of East Australia: the 35th Biodiversity Hotspot," in Biodiversity Hotspots: Distribution and Protection of Conservation Priority Areas, eds F. E. Zachos, and J. C. Habel, (Berlin: Springer-Verlag), 295-310. doi: 10.1007/978-3-642-20992-5_16

World Register of Marine Species [WoRMS] (2020). Polychaeta. http:// www.marinespecies.org/aphia.php? $\mathrm{p}=$ taxdetails\&id=883 (accessed February 10, 2020).

Wyrtki, K. (1973). "Physical oceanography of the Indian Ocean," in The Biology of the Indian Ocean, eds B. Zeitzschel, and S. A. Gerlach, (Berlin: Springer-Verlag), 18-36. doi: 10.1007/978-3-642-65468-8_3

Conflict of Interest: The authors declare that the research was conducted in the absence of any commercial or financial relationships that could be construed as a potential conflict of interest.

Copyright (C) 2020 Gopal, Abdul Jaleel, Parameswaran, Sanjeevan, Saramma, Vijayan, Saravanane, Gupta and Sudhakar. This is an open-access article distributed under the terms of the Creative Commons Attribution License (CC BY). The use, distribution or reproduction in other forums is permitted, provided the original author(s) and the copyright owner(s) are credited and that the original publication in this journal is cited, in accordance with accepted academic practice. No use, distribution or reproduction is permitted which does not comply with these terms. 